Journal of Aquaculture Feed Science and Nutrition 4 (1): 1-26, 2012

ISSN: $2070-1667$

(C) Medwell Journals, 2012

\title{
Alternative Protein Sources for Aquaculture Feeds
}

\author{
${ }^{1}$ Ferouz Y. Ayadi, ${ }^{2}$ Kurt A. Rosentrater and ${ }^{3}$ Kasiviswanathan Muthukumarappan \\ ${ }^{1}$ South Dakota State University, \\ ${ }^{2}$ USDA, ARS, North Central Agricultural Research Laboratory, \\ ${ }^{3}$ South Dakota State University, Brookings, 57007 SD, USA
}

\begin{abstract}
With a global seafood production of about 51.7 million ton in 2006 and an annual growth rate of $6.9 \%$ from 1970-2006, aquaculture is one of the fastest growing sectors in the food industry. Feed represents $40-70 \%$ of operating costs for aquaculture operations. Fish diets typically contain between 20 and $55 \%$ crude protein, depending on the fish species. High quantities of fish meal are commonly used in these feeds to supply fish with essential proteins, amino acids and fatty acids. However, during the last 3 years prices for fish meal have remained above $\$ 1000$ ton $^{-1}$ and have even approached $\$ 2000$ ton $^{-1}$ in 2010 . Increasing expenses and potential declining supplies of fish meal have led scientists to search for less expensive but compatible alternative protein sources for fish feed; most of which are based on animal or plant protein sources. The objective of this study is to review some alternative protein sources including animal byproducts (e.g., poultry byproducts), fishery byproducts, bacterial proteins, plant proteins (e.g., soybean meal, distillers dried grains with solubles and others). The problems and advantages of these alternatives (i.e., nutritive, levels of inclusion and their acceptability values in fish diets) will be discussed.
\end{abstract}

Key words: Aquaculture, DDGS, extrusion, fish feed, fish meal replacement, nutrition, processing, alternative proteins

\section{INTRODUCTION}

Due to health awareness and population growth, seafood consumption has been increasing for years. In 2009, global fish production was estimated at 142 million ton (metric ton) of which aquaculture produced approximately 52 million ton. World production of aquaculture with an annual growth rate of around $7 \%$, makes it one of the fastest growing animal food-producing sectors. Aquaculture products, composed of fish, crustaceans, mollusks, amphibians (such as frogs) and reptiles (such as turtles) have been steadily increasing whereas capture fisheries remained relatively stable at an estimated 90 million ton (FAO, 2009a, b). Depending on the species raised and specific feed requirements, aquaculture may actually increase the exploitation of endangered wild fishery stocks. For example, carnivorous fish require large amounts of fish meal and fish oil in their feeds which come from wild-caught fish. Fish production using little or no fish meal can reduce environmental problems (Naylor et al., 1998). Historically, dried fish has been used as an animal feed and fertilizer for thousands of years. Initially, fish meal was a byproduct of fish oil production but became a high protein feed ingredient in poultry and pig diets since the 1950s. Now-a-days, livestock diets contain considerable portions of soybean meal and corn, at least in the USA but in many countries fish meal is still used as the main protein source for animal diets (Hardy and Tacon, 2002). Fish meal has become the most important and cost-effective protein for commercial aquaculture feed. It provides fish with high quality protein, essential fatty acids, trace minerals (USB, 2008) has high palatability (Li et al., 2006) and promotes optimum growth performance (Gomes et al., 1995). Fish generally require between $25-55 \%$ protein in their diets, depending on the species and maturity (NRC, 1993).

For example, salmonids have the highest protein demand, needing $40-50 \%$ (or even higher) levels for fry (Hardy, 1996) whereas Nile tilapia (Oreochromis niloticus) typically require $30-45 \%$ dietary protein for optimum performance (Al Hafedh et al., 1999; Abdel-Tawwab et al., 2010); channel catfish (Ictalurus punctatus) require $30-35 \%$, depending on the protein source and age of fish (Reis et al., 1989). Variation in dietary protein for optimal growth can also be caused by hygiene, environmental conditions and stocking density (Abdel-Tawwab et al., 2010). Amino acids are the determining factor to meet the metabolic demands of fish (Guimaraes et al., 2008). Deficiencies in Essential Amino Acids (EAA) can lead to inferior protein utilization and result in reduced growth

Corresponding Author: Kurt A. Rosentrater,USDA, ARS, North Central Agricultural Research Laboratory, Brookings, 57007 SD, USA 
and decreased feed efficiency ratios (Anderson et al., 1992). Salmon diets usually contain about 40-60\% fish meal (Gillund and Myhr, 2010) while tilapia diets contain 20-30\% (or less) fish meal (El-Saidy and Gaber, 2002; Hernandez et al., 2010). Different dietary protein sources vary in their nutritional and biological values and differ in digestibility and amino acid composition (Anderson et al., 1992).

Protein is not the only important dietary component, however lipids, fibers, carbohydrates and antinutritional factors are also essential to proper nutrition. Fish require certain amounts of dietary lipids as sources of energy and essential fatty acids. The amount of lipid needed varies between species. For example, optimal levels for juvenile grouper (Epinephelus malabaricus) are about 9\% (Lin and Shiau, 2003) both juvenile hybrid tilapia (Oreochromis niloticus $\mathrm{x}$ Oreochromis aureus) (Chou and Shiau, 1996) and juvenile European sea bass (Dicentrarchus labrax) require about 12\% lipids to achieve maximum growth (Peres and Oliva-Teles, 1999). Rainbow trout (Oncorhynchus mykiss) in contrast, require at least 16\% lipids (Lee and Putnam, 1973). Generally, salmonids grow well on diets containing up to $20 \%$ lipid (Jackson et al., 1984). An imbalance in digestible energy-to-Crude Protein (CP) ratio, excessive fat deposition (NRC, 1993; Peres and Oliva-Teles, 1999; Regost et al., 2001) and growth depression (Lin and Shiau, 2003) may result from feeding too high amounts of dietary lipid if the lipid level is lower than needed, however some fish such as rainbow trout can convert protein into fat (Lee and Putnam, 1973). Fibers are indigestible and nutritionally unavailable carbohydrate components in animal and plant sources and are commonly used as fillers or binders in fish feed (Dias et al., 1998). Fish can tolerate up to a certain amount of dietary fiber in their feed which is generally $>10 \%$, before it begins to affect growth rate (Anderson et al., 1984; Del Carmen Gonzalez-Pena et al., 2002).

There are no specific carbohydrate requirements for fish. Fish can utilize protein, fat and other components in their feed if no carbohydrates are present. It is recommended to add digestible carbohydrates to fish diets (NRC, 1993) since, certain species show reduced growth without them. For marine or coldwater fish concentrations of up to $20 \%$ carbohydrates seem to be optimal whereas fresh or warm water fish require concentrations $>20 \%$. Additionally, carbohydrates are the least expensive source of dietary energy (Wilson, 1994). Antinutritional Factors (ANF) such as trypsin inhibitors, hemagglutinating agents, phytic acids, gossypols, cyclopropenoic fatty acids, glucosinolates, erucic acids, alkaloids and thiaminases are substances found in plant sources that can affect fish performance can reduce digestibility or even prove toxic to fish (NRC, 1993). Fish meals are classified by the type of fish or the species of origin. Commonly used fish for fish meals include herring, menhaden and anchovy and others. They vary in their amino acid profiles and proximate compositions (USB, 2008). For the USA market, menhaden is the major fish source used for fish meal (Ingredients101, 2010a). Sinc, the 1980's intensive farming of salmon and trout has led to greater use of fish meal in fish diets.

Consequently, by 2008 nearly $60 \%$ of global fish meal supplies were utilized in aquaculture whereas use in pig and poultry feeds decreased to 31 and $10 \%$, respectively (Jackson, 2009). Almost 70\% of global fish meal has been fed to salmon, trout and shrimp, despite the fact that these species account for only $7 \%$ of global aquaculture production (Hardy, 2000). This is due to their need for high protein and high energy feeds.

Fish meal production was recorded at 2.6 million ton in 2008 with a decrease of 100,000 ton compared to 2007 (FAO, 2009a). In 2006, $>77 \%$ of world fish production was used for human consumption whereas about 33\% was used for fish meal and fish oil manufacture (FAO, 2009a). Overall, feeding costs generally represent the highest amount of total operating expenses of an aquaculture operation even up to $70 \%$ in some instances (Metts et al., 2007; Thompson et al., 2008). In Mediterranean aquaculture between 1.5 and $2.5 \mathrm{~kg}$ of feed are needed to produce $1 \mathrm{~kg}$ of fish; this makes up around $45 \%$ of production expenses (Martinez-Llorens et al., 2008). This is true particularly for carnivorous species such as salmonid diets (Meyers, 1994) because protein is the costliest component in aquaculture diets (Nguyen et al., 2009).

Based on increasing expenses, limited sources of fish meal, increasing demands and overfishing of wild stocks, numerous studies on plant protein sources, bacterial protein meal, fishery and animal byproducts have been conducted to examine the feasibility of replacing fish meal partially or even totally, in diets for different fish species. In addition, plant protein sources are relatively easy to obtain and their cost per unit is generally lower compared to fish meal (The FishSite, 2010). In 2004/2005, the average price of fish meal containing $60 \%$ protein was $\$ 630$ ton $^{-1}$, compared to $\$ 876$ ton $^{-1}$ in $2008 / 2009$ whereas the average price from October, 2009 to July, 2010 increased from $\$ 1120$-1516 ton $^{-1}$ for the US east coast (USDA, 2010a). Previous studies have shown that fish meal can be effectively replaced by alternative protein sources (Kaushik et al., 1995; El-Sayed, 1998; Goda et al., 2007). Investigations for fish meal replacement are often for a single alternative protein source and can result in a high 
percentage of substitution but seldom equivalent values for growth performance, survival rate and specific weight gain. Essential amino acid composition, particularly lysine and methionine are lower in plant and animal sources than in fish meal and often have to be supplemented to achieve growth rates and weight gain of equal values. Various studies of total replacements for fish meal have also been accomplished using mixtures of alternative protein sources. In the majority of these cases, at least one portion was an animal protein source such as poultry byproduct meal, meat and bone meal, feather meal or blood meal (Wang et al., 2010a).

An important aspect of any substitute is the nutritional value of the alternative protein source. Rendered animal byproduct meals such as meat and bone meal, blood meal, feather meal and poultry byproduct meal are initially waste products from livestock and poultry production. They have been used for decades in salmonid feeds, however inclusion has been limited due to poor digestibility and large variations in quality. In addition, the nutritional quality is affected by the raw material composition, freshness and processing conditions (Bureau et al., 1999). Although, protein content and quality from alternative protein sources is often inferior to fish meal, high substitution levels through proper preprocessing and supplementation with EAA are possible and are already applied in many commercial fish diets.

The objective of this study is to review some potential alternative protein sources for fish meal. These include fish meal from fishery discard, fish processing byproducts, fish silage from processing wastes, meat and bone meal, blood meal, poultry-by products, feather meal, bacterial protein meal, soybean meal, soy protein concentrate, soy protein isolate, corn gluten meal, corn gluten feed, distillers dried grains with solubles, alfalfa meal, cottonseed meal, rapeseed meal, lupin seed meal, pea, lentil, chickpea, navy bean, pinto bean and black bean meal. Discussion includes processing, nutritive values, inclusion levels in previous fish feeding trials, availabilities and prices of these protein sources.

\section{MATERIALS AND METHODS}

\section{Fishery products:}

Fish meal: Fish meal is mostly produced from whole pelagic (i.e., surface-dwelling fish not bottom-dwelling) fish (e.g., anchovy, herring, mackerel, menhaden, sardine, tuna) or seafood processing byproducts such as processing waste, viscera and other unused parts of fish (Hardy and Tacon, 2002; Yano et al., 2008) that have little or no use for human consumption. Fish meal is generally light brown in color and is produced by cooking, pressing, drying and milling fresh raw fish and fish trimmings. It can be sold as four types; high quality meal, which is usually used in small-scale aquaculture units such as trout farms or marine species, low temperature meal which is highly digestible and used in salmon production, prime meal and fair/average quality meal which has lower protein content and is used for pig and poultry feeds (FIN, 2009).

Fish meal made of anchovy, herring, mackerel, menhaden or sardine can often have Crude Protein (CP) content between $67.4-89.6 \%$ (dry basis, db), 7.3-15.7\% $(\mathrm{db})$ crude fat, $0.5-1.1 \%(\mathrm{db})$ crude fiber, $11.2-22.3 \%(\mathrm{db})$ ash, $4.6-6.9 \%(\mathrm{db})$ lysine and $1.7-2.7 \%(\mathrm{db})$ methionine (Table 1 and 2).

Fish meal is mixed with other ingredients in fish feed (e.g., trout diets contain about $20-30 \%$ fish meal whereas catfish feed is predominantly based on soybean meal (50-55\%) and corn (25-35\%) and often contains only a small portion of fish meal) (Hammoumi et al., 1998).

Fish waste, fishery byproducts and/or discarded fish: Because of limited availability of wild caught fish and rising prices, feeding expenses can account for $40-80 \%$ of production costs (Rawles et al., 2010). Consequently, whole fish used in fish meal processing may be limited in the near future. Approximately half of processed seafood is discarded as waste material (Yano et al., 2008). Moreover, unintended by-catch such as other fish, mammals, turtles and birds are non-target organisms that are accidently captured and then discarded back into the

Table 1: Proximate composition for various fish meals $(\%, \mathrm{db})^{*}$

\begin{tabular}{|c|c|c|c|c|c|c|c|}
\hline Fish meal type & Crude protien $(\%)$ & Crude fat $(\%)$ & Crude fiber $(\%)$ & NDF $(\%)$ & $\mathrm{ADF}(\%)$ & $\mathrm{ASH}(\%)$ & References \\
\hline Anchovy & $71.2-89.6$ & $10.0-11.4$ & $0.5-1.1$ & $\mathrm{NA}$ & NA & $12.4-19.2$ & $\begin{array}{l}\text { Anderson et al. (1993), NRC (2001), } \\
\text { Hardy et al. (2005), Batal and Dale (2009) and } \\
\text { Kop and Korkut (2010) }\end{array}$ \\
\hline Herring & $77.4-86.0$ & $9.1-15.7$ & $0.7-1.1$ & NA & NA & $11.2-15.5$ & $\begin{array}{l}\text { Anderspn et al. (1993), NRC (2001) and } \\
\text { Batal and Dale (2009) }\end{array}$ \\
\hline Mackerel & 71.2 & 10.3 & NA & NA & $\mathrm{NA}$ & 15.0 & Alibaba Group (2010) \\
\hline Menhaden & $67.4-70.4$ & $10.4-11.1$ & $0.8-1.1$ & NA & NA & $20.4-22.3$ & $\begin{array}{l}\text { Anderspn et al. (1993), NRC (2001) and } \\
\text { Batal and Dale (2009) }\end{array}$ \\
\hline Sardine & $67.4-73.3$ & $7.7-8.3$ & 1.1 & NA & NA & $12.8-17.2$ & $\begin{array}{l}\text { Mesomya et al.(2002), Harnandez et al. (2008) } \\
\text { and Batal and Dale (2009) }\end{array}$ \\
\hline Tune & $57.0-64.4$ & 7.3 & $0.9-5.4$ & NA & NA & $23.5-26.9$ & NRC (2001) and Batal and Dale (2009) \\
\hline
\end{tabular}

*All data converted to a dry matter basis. NDF: Neutral Detergent Fiber; ADF: Acid Detergent Fiber, NA: Not Available 
Table 2: Essential amino acid profiles for various fish meals $(\%, \mathrm{db})$

\begin{tabular}{|c|c|c|c|c|c|c|c|c|c|c|c|}
\hline Fishmeal type & $\operatorname{Arg}(\%)$ & His $(\%)$ & lle $(\%)$ & Leu $(\%)$ & Lys $(\%)$ & Met $(\%)$ & Phe $(\%)$ & $\operatorname{Thr}(\%)$ & $\operatorname{Trp}(\%)$ & Val $(\%)$ & References \\
\hline Anchovy & $3.7-4.6$ & $1.6-2.5$ & $2.8-4.0$ & $5.4-6.3$ & $4.6-6.2$ & 2.1 & $2.6-3.4$ & $2.8-3.2$ & $0.3-0.8$ & $3.4-4.1$ & $\begin{array}{l}\text { Anderson et al. (1993), NRC (1998), } \\
\text { Glencross et al. (2005) and } \\
\text { Batal and Dale (2009) }\end{array}$ \\
\hline Terring & $4.3-6.6$ & $1.4-2.1$ & $3.1-4.4$ & $5.2-7.3$ & $5.8-6.9$ & $1.7-2.7$ & $2.7-3.7$ & $1.7-3.3$ & $0.8-1.2$ & $3.7-6.1$ & $\begin{array}{l}\text { 3), NRC (1998) and } \\
09)\end{array}$ \\
\hline & & & & & & & & & & & \\
\hline Menhaden & & $1.5-1.9$ & $2.8-3.6$ & $4.8-5.6$ & & $1.9-2.4$ & $2.7-2.9$ & $2.8-3.2$ & $0.4-0.7$ & & $\begin{array}{l}\mathrm{NRC}(1998) \text { and } \\
\text { 8) }\end{array}$ \\
\hline Sardine & $2.9-5.5$ & $1.3-2.4$ & $2.8-3.6$ & $4.1-5.2$ & $4.8-6.4$ & $1.9-2.2$ & $2.2-2.9$ & $2.8-3.0$ & 0.5 & $3.2-3.6$ & $\begin{array}{l}\text { Hernandez et al. }(2008) \\
\text { Batal and Dale (2009) }\end{array}$ \\
\hline Cune & $3.4-3.7$ & 1.9 & 2.6 & & $4.2-4.4$ & 1.6 & $2.3-2.7$ & $2.5-2.7$ & $0.6-0.8$ & 3.0 & NRC (1993) and Batal and Dale (2009) \\
\hline
\end{tabular}

*All data converted to a dry matter basis

Table 3: Proximate composition for various animal byproducts $(\%, \mathrm{db})^{*}$

\begin{tabular}{|c|c|c|c|c|c|c|c|}
\hline $\begin{array}{l}\text { Animal } \\
\text { byproducts }\end{array}$ & Crude protein & Crude fat & $\begin{array}{l}\text { Crude fiber } \\
--(\%)---\end{array}$ & NDF & $\mathrm{ADF}$ & Ash & References \\
\hline $\begin{array}{l}\text { Fish meal } \\
\text { (fish waste) }\end{array}$ & $56.5-80.0$ & $5.2-34.4$ & 0.07 & NA & NA & $6.5-26.8$ & $\begin{array}{l}\text { Millamena (2002), Li et al. (2004), Hardy et al. (2005) and } \\
\text { Goddard et al. (2008) }\end{array}$ \\
\hline $\begin{array}{l}\text { Fish silage } \\
\text { (fish waste) }\end{array}$ & $31.6-56.5$ & $5.9-7.5$ & $6.8-8.3$ & NA & NA & $11.4-23.5$ & Hammoumi et al. (1998), Hossain et al. (1997) and Geron et al. (2007) \\
\hline MBM & & & & 34.9 & 6 & & NRC $(1$ \\
\hline $\mathrm{BM}$ & $80.0-98.8$ & $0.0-1.7$ & $0.0-1.1$ & 14.8 & 26.4 & $1.0-3.1$ & $\begin{array}{l}\text { NRC (1998), Allan et al. (2000), Bureau et al. (2000), } \\
\text { Fasakin et al. (2005) and Martinez-Llorens et al. (2008) }\end{array}$ \\
\hline PBM & $58.0-64.2$ & $12.0-17.1$ & $2.1-2.5$ & $0.0-2.5$ & NA & $15.6-22.5$ & NRC (1993), Fasakin et al. (2005) and Guimaraes et al. (2008) \\
\hline FEM & $89.6-92.4$ & $3.3-11.2$ & $1.3-3.3$ & 1.5 & 17.6 & $3.0-4.2$ & $\begin{array}{l}\text { NRC (1993), Allan et al. (2000), Batal and Dale (2009) and } \\
\text { Ingredients101 (2010d) }\end{array}$ \\
\hline BPM & $67.0-68.1$ & $8.1-10.4$ & NA & NA & NA & $6.2-8.1$ & Skrede et al. (1998), Storebakken et al. (2004) and Aas et al. (2006 a, b) \\
\hline
\end{tabular}

*All data were converted to on a dry matter basis; MBM: Meat and Bone Meal; BM: Blood Meal; PBM: Poultry byproduct Meal; FEM: Feather Meal; BPM: Bacterial Protein Meal; NDF: Neutral Detergent Fiber; ADF: Acid Detergent Fiber; NA: Not Available

Table 4: Essential amino acid profile of various animal protien sources $(\%, \mathrm{db})^{*}$

\begin{tabular}{|c|c|c|c|c|c|c|c|c|c|c|c|}
\hline $\begin{array}{l}\text { Animal } \\
\text { byproducts }\end{array}$ & \begin{tabular}{r} 
Arg \\
- \hdashline-
\end{tabular} & His & lle & Leu & $\begin{array}{l}\text { Lys } \\
---(\%)\end{array}$ & Met & Phe & Thr & $\operatorname{Trp}$ & Val & References \\
\hline $\begin{array}{l}\text { Fish meal } \\
\text { (fish waste) }\end{array}$ & $3.8-6.1$ & $1.0-1.9$ & $2.0-4.1$ & $3.1-6.5$ & $2.0-5.2$ & $1.0-2.3$ & $2.2-3.6$ & $2.2-4.0$ & NA & $2.3-4.1$ & Li et al. (2004) \\
\hline $\begin{array}{l}\text { Fish silage } \\
\text { (fish waste) }\end{array}$ & $1.9-3.0$ & $1.0-1.4$ & $1.2-3.2$ & $2.4-3.5$ & $2.4-3.3$ & $1.9-2.2$ & $1.3-2.2$ & $1.6-2.1$ & $0.2-0.4$ & $1.4-3.0$ & Borghesi et al. (2008) \\
\hline MBM & $3.2-4.3$ & $0.6-1.2$ & $1.1-1.8$ & $2.3-3.5$ & $2.3-3.5$ & $0.5-1.1$ & $1.5-1.9$ & $1.2-2.1$ & $0.2-0.3$ & $1.8-2.6$ & $\begin{array}{l}\text { NRC (1993), Allan et al. (2000) and } \\
\text { Guimaraes et al. (2008) }\end{array}$ \\
\hline $\mathrm{BM}$ & $2.4-4.0$ & $3.0-6.0$ & $0.8-1.0$ & $9.8-11.6$ & $6.9-8.0$ & $0.7-1.5$ & $5.4-6.3$ & $3.1-5.4$ & $0.8-1.7$ & $5.2-8.2$ & $\begin{array}{l}\text { NRC (1993), Allan et al. (2000), } \\
\text { Kats et al. (1994), Sauvant (2004) and } \\
\text { Ingredients101 (2010b) }\end{array}$ \\
\hline PBM & $3.7-4.6$ & $1.2-1.5$ & $2.2-2.7$ & $4.2-4.6$ & $2.4-5.0$ & $1.0-1.4$ & $1.7-2.5$ & $1.0-2.5$ & $0.4-0.5$ & $2.5-3.3$ & $\begin{array}{l}\text { NRC (1993), Guimaraes et al. (2008) } \\
\text { and Batal and Dale (2009) }\end{array}$ \\
\hline FEM & $5.7-6.7$ & $0.5-1.1$ & $3.9-4.9$ & $6.8-8.0$ & $1.8-2.9$ & $0.6-0.7$ & $4.1-4.6$ & $4.0-4.7$ & $0.4-0.6$ & $5.6-7.3$ & $\begin{array}{l}\text { NRC (1993), Allan et al. (2000), } \\
\text { Sauvant (2004) and } \\
\text { Guimaraes et al. (2008) }\end{array}$ \\
\hline BPM & $3.9-4.5$ & $1.2-1.6$ & $2.5-3.4$ & 4.4-5.5 & $3.1-4.3$ & $1.5-2.1$ & $2.3-3.1$ & $2.5-3.4$ & $0.8-1.5$ & $3.2-4.3$ & Skredaet cl. (1998) and Aas et cl. (2007) \\
\hline
\end{tabular}

*All data were converted to on a dry matter basis; MBM: Meat and Bone Meal; BM: Blood Meal; PBM: Poultry Byproduct Meal; FEM: Feather Meal; BPM: Bacterial Protein Meal

sea because they are not needed (Harrington et al., 2005). Since, this negatively affects the environment, processing of fish waste to fish meal represents is a promising alternative method of waste utilization. However, fish waste varies highly in its physical nature and proximate composition. For example, fish waste consisting of intestines has high lipid but low protein contents (Yano et al., 2008). The raw waste materials vary in nutritional values, depending on the size of fish and may require special preservation to maintain quality (Goddard et al., 2008). Depending on the raw waste used, fish meal based on by-catch or fish waste may contain between $56.5-80.0 \%(\mathrm{db}) \mathrm{CP}, 5.2-34.4 \%(\mathrm{db})$ crude fat, $0.07 \%(\mathrm{db})$ crude fiber, $6.5-26.8 \%(\mathrm{db})$ ash, $2.0-5.2 \%(\mathrm{db})$ lysine and $1.0-2.3 \%(\mathrm{db})$ methionine (Table 3 and 4). Generally, seafood waste is only available during the fishing season often from poorly accessible areas where it is difficult to process. Sometimes, it can be preserved as press cake meal (Hardy et al., 2005). In seafood processing plants, up to $50 \%$ of the processed fish can result in waste material (Ferraz de Arruda et al., 2007). Fish waste is composed of body parts that are not consumable 
by humans and can include heads, fins, viscera, scales and under-sized fish (Pagarkar et al., 2006; Yano et al., 2008). Large quantities of fish waste resulting from inefficient processing can result in a high environmental burden. To avoid increasing pollution due to waste disposal problems, this low-cost material could be used as fish feed. Previous studies have reported that fish meals produced from discarded fishery waste and processing byproducts can be suitable as a total or partial replacement for commercial fish meal for rainbow trout (Hardy et al., 1983, 2005; Stone et al., 1989), tilapia (Goddard et al., 2008; Chitmanat et al., 2009) and red drum (Sciaenops ocellatus) (Li et al., 2004; Whiteman and Gatlin, 2005). Hardy et al. (2005) suggested that limiting factors such as chitin and bones should be removed and diets should be supplemented with amino acids and minerals to successfully use higher inclusion levels of these meals in commercial rainbow trout diets.

Fish silage: Another alternative method to use fish waste can be the production of fish silage. Compared to fish meal, the production of fermented fish silage requires less technology and cost and is relatively easy to produce (Fagbenro et al., 1997; Ferraz de Arruda et al., 2007). On the other hand, transportation costs can be high due to high water content (Rustand, 2003). Fish silage is a liquid or semi-liquid product that can be preserved using microbial fermentation (Borghesi et al., 2008). Fish silage is made of low-value whole fish or fish parts that are ensiled by fermentation using lactic acid bacteria that either exist naturally in the fish waste or are inoculated as starter cultures. Enzymes can also be added to the starter cultures (Tatterson and Windsor, 1974) or enzymes can be used as a sole source of liquefaction (Borghesi et al., 2008). Another common way to liquefy fish waste is by adding 2-3\% formic acid and storing at room temperature for several days until pepsins and other acid proteases in the fish tissue have dissolved the raw material. $\mathrm{A} \mathrm{pH}$ of 3-4 generally indicates that the silage is well preserved (Rustand, 2003). Fish silage contains typically high amounts of unsaturated lipids that may be oxidized and form toxic products causing cellular changes.

Jackson et al. (1984) suggested adding antioxidants to increase storage life. Fish silage generally contains 31.6-56.5\% (db) CP, 5.9-7.5\% (db) crude fat, 6.8-8.3\% (db) crude fiber, $11.4-23.5 \%(\mathrm{db})$ ash, $2.4-3.3 \%(\mathrm{db})$ lysine and $1.9-2.2 \%(\mathrm{db})$ methionine (Table 3 and 4 ). The lower protein in fish silage compared to fish meal is due to the liquefaction which can convert the proteins to polypeptides and free amino acids (Tatterson and Windsor, 1974). Traditionally, fish silage has been used as a dietary ingredient for poultry and swine feed
(Ferraz de Arruda et al., 2007). Crop residues and/or crop byproducts can be used as fillers in the fish silage to achieve better drying characteristics (Fagbenro and Jauncey, 1994) during preparation of fish diets. Studies have reported that fish silage can be successfully integrated into diets for rainbow trout (Stone et al., 1989), Atlantic salmon (Salmo salar) (Lie et al., 1998), juvenile Nile tilapia (Fagbenro and Jauncey, 1994), juvenile pacu (Piriactus mesapotamicus) (Vidoiti et al., 2002) and juvenile catfish (Fagbenro et al., 1997) as a highly digestible fish meal alternative. Neutralized, dried fish silage replaced fish meal in trout diets but resulted in lower growth rate, although it did not affect final weight or palatability. The authors hypothesized that the inferior growth rate was caused by less intact protein and higher portion of free amino acids (Stone et al., 1989).

\section{Animal protein sources}

Meat and Bone Meal (MBM): High amounts of meat and bone meal are steadily produced in the USA and other industrialized countries. In fact, the meat industry produces most of the organic waste in the food processing sector (Banks and Wang, 2006). MBM is a product of animal rendering and is produced from animal waste tissues that are not used for human foods. It consists of trimmings, bones, viscera, undigested feed, blood, heads, hooves, hides and/or dead livestock (Shirley and Parsons, 2001). The variety of raw materials often results in large variations in chemical composition and protein quality. MBM has been primarily used as a high protein supplement in animal diets for many years. But due to the Bovine Spongiform Encephalopathy (BSE) crisis in 1990's, MBM has been prohibited for use in ruminant feeds in many countries.

Moreover, particularly in the European Union, MBM is hardly used in traditional feed markets any more (Garcia and Rosentrater, 2008). Depending on the source, $\mathrm{CP}$ content is around $47.3-54.3 \%(\mathrm{db})$, crude fat is $7.2-10.3 \%(\mathrm{db})$, crude fiber is $2.5-2.6 \%(\mathrm{db})$ and ash is $31.1-41.3 \%(\mathrm{db})$. Lysine content $(2.5-3.5 \% \mathrm{db})$ and methionine $(0.5-1.5 \% \mathrm{db})$ are lower than fish meal (Table 3 and 4). In 2004/05, the average price for MBM for the Central USA was $\$ 181$ ton $^{-1}$, compared to $\$ 356$ ton $^{-1}$ in 2008/2009 (USDA, 2010a).

For years MBM has been fed to salmonids (Bureau et al., 2000). MBM is commonly included in commercial fish diets but generally at levels not $>20 \%$. In experimental studies, various results were reported for diverse species. For example for Nile tilapia fingerlings, $40 \% \mathrm{MBM}$ was used in combination with $36 \%$ wheat bran and $10 \%$ corn starch and totally replaced fish meal in a $30 \%$ CP diet; results indicated no significant differences 
in weight gain, specific growth rate or survival rate (El-Sayed, 1998). In diets for rainbow trout, MBM at 24\% inclusion replaced fish meal up to $32 \%$ in a $48 \%$ CP diet (Bureau et al., 2000). For juvenile hybrid striped bass (Morone chrysops $\mathrm{x}$ M. saxatilis), MBM could be used as the primary protein source at $45 \%$ inclusion level in a $44 \%$ CP diet (Bharadwaj et al., 2002). Webster et al. (2000) concluded that juvenile sunshine bass fed a diet of $35 \%$ soybean meal and $35 \%$ meat and bone meal resulted in higher weight gain, specific growth rate and survival than the control diet which contained 30\% fish meal. For juvenile Japanese flounder (Paralichthys olivaceus), 18\% MBM replaced 20\% fish meal in a $48 \%$ CP diet (Kikuchi et al., 1997) without compromising growth rate or weight gain. When using MBM, reduced growth may be due to deficiencies in EAA such as methionine, lysine and isoleucine. Furthermore, MBM may exhibit lower digestibilities (Millamena, 2002). In studies with Nile tilapia, diets formulated with MBM resulted in the lowest apparent protein digestibility $(78.4 \%)$ compared to fish meal which was $88.6 \%$ (Guimaraes et al., 2008).

Blood Meal (BM): Blood meal is made of blood from animal processing plants and dried after the whole blood has been centrifuged to remove foreign material (Ingredients101, 2010b). Spray, ring or flash-drying systems can be used to process the blood and to eliminate pathogens (Martinez-Llorens et al., 2008). It is a high-quality protein product with $\mathrm{CP}$ levels varying between $80.0-98.8 \%(\mathrm{db}), 0.0-1.7 \%(\mathrm{db})$ crude fat, $0.0-1.1 \%(\mathrm{db})$ crude fiber, excess concentrations of lysine $(6.9-8.0 \%, \mathrm{db})$ and low concentrations of methionine $(0.7-1.5 \%, \mathrm{db})$ (Table 3 and 4). Regarding essential amino acid content, $\mathrm{BM}$ is deficient in isoleucine but has excess histidine, leucine, phenylalanine, threonine and valine compared to fish meal (Table 2 and 4). These EAA imbalances can lead to negative effects in fish performance. On the other hand, enrichment in isoleucine can balance these adverse effects (Yamamoto et al., 2004). In June 2009, ruminant BM prices were about $\$ 785$ ton $^{-1}$ and in June, 2010 about $\$ 930$ ton $^{-1}$ (The Jacobsen Price Guide, 2010). Similar to meat and bone meal, ruminant BM has generally been avoided in animal and fish diets to protect against Bovine Spongiform Encephalopathy (BSE) (Fasakin et al., 2005). Porcine BM, however is commonly used in ruminant diets. High dietary inclusion levels of BM have not been effective in growth performance for most fish species, considering the fact that small inclusion levels of BM have generally been substituted for fish meal. For Nile tilapia fingerlings, $10 \%$ inclusion of BM, constituting $31 \%$ protein of the CP in the diet, resulted in satisfactory production and average weight gain
(Otubusin, 1987). In a 47\% CP diet for juvenile and growing gilthead sea bream (Sparus aurata), BM could be included between 5 and $15 \%$ for fish meal without affecting growth performance and survival rate (Martinez-Llorens et al., 2008). Several studies have been conducted with rainbow trout diets incorporating 5\% BM(Satoh et al., 2003), 6-1 2\% BM (El-Haroun et al., 2009) and up to $23 \% \mathrm{BM}$ without affecting growth performance and survival; the latter diet contained $23 \%$ blood powder as the primary protein source in a $47 \% \mathrm{CP}$ diet, replacing $65 \%$ of the herring meal (Luzier et al., 1995). BM at $8 \%$ inclusion in combination with meat meal (32\% inclusion level) replaced $80 \%$ of fish meal in a $45 \% \mathrm{CP}$ diet for juvenile grouper (Epinephelus coioides) with similar growth rates and weight gain as the fish meal-based control diet (Millamena, 2002). Prices for pork and other non-ruminant $\mathrm{BM}$ are more expensive than ruminant blood because there are limited amounts available.

Poultry Byproduct Meal (PBM): Poultry production is one of the fastest growing agricultural sectors (Zielinska et al., 2007) and produces increasing quantities of wastes and byproducts. Slaughterhouse wastes can be recycled as a potential source of protein in fish diets (Kherrati et al., 1998). Poultry byproducts consist of feet, heads, undeveloped eggs, gizzards and viscera (FAO, 2010a). Depending on the source, PBM can contain approximately $58.0-64.2 \%(\mathrm{db}) \mathrm{CP}, 12.0-17.1 \%(\mathrm{db})$ crude fat, $2.1-2.5 \%(\mathrm{db})$ crude fiber and $15.6-22.5 \%(\mathrm{db})$ ash (Table 3). Regarding the EAA profile, values are similar to the EAA of fish meal except for methionine which is lower at $1.1-1.4 \%(\mathrm{db})$. Lysine content varies between $3.1-5.0 \%(\mathrm{db})$ (Table 4). Processing conditions affect the quality of PBM, its protein and amino acid availability and digestibility (Thompson et al., 2008).

PBM has been used in commercial diets for a variety of fish species such as sunshine bass and hybrid striped bass (Rawles et al., 2009, 2010). PBM has been evaluated as a potential feed ingredient for juvenile male hybrid tilapia where $67 \%$ of the fish meal could be replaced with $30 \% \mathrm{PBM}$ in a $35 \% \mathrm{CP}$ diet (Fasakin et al., 2005). In Nile tilapia fingerling diets, PBM at 47 and $27 \%$ inclusion levels with other non-fish meal sources totally replaced fish meal in 30 and $34 \%$ CP diets, respectively without differences in growth or weight gain (El-Sayed, 1998; Hernandez et al., 2010). It has also been examined in rainbow trout diets where 37 and 40\% fish meal was replaced with 20\% $\mathrm{PBM}$ and $30 \% \mathrm{PBM}$ in $45 \%$ and $50 \%$ CP diets, respectively (Sevgili and Erturk, 2004; El-Haroun et al., 2009). PBM combined with feather meal at $27 \%$ inclusion and supplemented with methionine and lysine could substitute for $50 \%$ fish meal in practical 
$51 \% \mathrm{CP}$ diets for rainbow trout without compromising weight gain or specific growth rate (Steffens, 1994). Using high-quality PBM at 30\% inclusion level allowed a total replacement of fish meal in diets for hybrid striped bass in a $37 \%$ CP diet combined with soybean meal (32\%), wheat $(20 \%)$ and corn meal (12\%) (Pine et al., 2008) as well as $35 \%$ PBM with soybean meal $(26 \%)$, wheat $(15 \%)$ and cottonseed meal $(5 \%)$, supplemented with lysine and methionine in a 43\% CP diet (Rawles et al., 2009).

Feather meal: Feathers are byproducts of broiler, Turkey and poultry processing operations. If they are left unprocessed, they are not digestible. Processing of feather meal is conducted by steam hydrolysis under high pressures and temperatures followed by drying and grinding (Chandler, 2009). Feather meal is commonly fed to monogastric and ruminant animals (FAO, 2010b) and has proximate concentrations of $89.6-92.4 \%$ (db) $\mathrm{CP}$, $3.3-11.2 \%(\mathrm{db})$ crude fat, $1.3-3.3 \%(\mathrm{db})$ crude fiber and $3.0-4.2 \%(\mathrm{db})$ ash. Feather meal has $1.8-2.9 \%(\mathrm{db})$ lysine and $0.6-0.7 \%(\mathrm{db})$ methionine which is lower than fish meal. It has excess phenylalanine, threonine and valine (Table 3 and 4). The average price for feather meal in $2004 / 05$ in Arizona was $\$ 268$ ton $^{-1}$ and in $2008 / 09$, it was $\$ 503$ ton $^{-1}$ (USDA, 2010a).

Feather meal has been used for several years in aquafeeds, however poor digestibility and variations in quality have limited its use (Bureau et al., 2000). For Nile tilapia, poultry feather meal has one of the lowest apparent protein digestibilities among animal products such as PBM and fish meal (Guimaraes et al., 2008). Recently, improved processing conditions have resulted in relatively higher digestibilities (Bureau et al., 1999). In $54-57 \%$ CP diets for juvenile rainbow trout, feather meal could be included up to $15 \%$ without affecting growth, feed efficiency, nitrogen or energy gains for the same level of fish meal (Bureau et al., 2000). Other studies have reported partial replacement of dietary fish meal with feather meal up to $20 \%$ for Indian major carp fry (Labeo rohita) in a 35\% CP diet compensating for $50 \%$ of the fish meal (Hasan et al., 1997) and up to $10 \%$ for Nile tilapia fry in a $25 \% \mathrm{CP}$ diet replacing $66 \%$ of the fish meal (Bishop et al., 1995) without compromising growth and feed utilization.

Bacterial Protein Meal (BPM): Bacterial protein meal is produced by fermentation for protein synthesis with bacteria cultures consisting of Methylococcus capsulatus, Alcaligenes acidovorans, Bacillus brevis and Bacillus firmus often using methane as an energy and carbon source and ammonia as a nitrogen source (Skrede et al., 1998; Aas et al., 2006a). In this aerobic process, bacterial biomass is continuously harvested, short-time heat treated to obtain a sterile product, centrifuged then spray-dried. BPM generally contains about $67.0-68.1 \%(\mathrm{db}) \mathrm{CP}, 8.1-10.4 \%(\mathrm{db})$ crude fat and $6.2-8.1 \%(\mathrm{db})$ ash (Table 3 ); crude fiber has not been reported. Compared to fish meal, BPM contains similar levels of EAA such as a lysine content of 3.1-4.3\% (db) and methionine of $1.5-2.1 \%(\mathrm{db})$ whereas tryptophan is lower at $0.8-1.5 \%(\mathrm{db})$ (Table 4). BPM has been investigated in diets for Atlantic salmon fry where at least $19 \%$ BPM compensated for up to $29 \%$ fish meal in a $48 \%$ $\mathrm{CP} \operatorname{diet}$ (Storebakken et al., 2004). In other studies, up to $36 \%$ BPM inclusion levels were substituted for $46 \%$ of the fish meal in a $51 \% \mathrm{CP}$ diet (Aas et al., 2006a). For rainbow trout, up to $31 \%$ fish meal could be replaced with $15 \%$ $\mathrm{BPM}$ inclusion in a $40 \% \mathrm{CP}$ diet (Overland et al., 2006). In other experiments, $27 \%$ inclusion of BPM in a $50 \% \mathrm{CP}$ diet could replace $36 \%$ of the fish meal (Aas et al., 2006b). In contrast, the incorporation of BPM in diets for Atlantic halibut (Hippoglossus hippoglossus) was only successful at $9 \%$ inclusion levels, compensating for $12 \%$ of fish meal in a 49\% CP diet (Aas et al., 2007).

\section{RESULTS AND DISCUSSION}

Plant protein sources: Leguminous crops include peas and beans of which soybean has been the most investigated and used plant protein source in aquafeeds (Davis et al., 2002). Studies with other plant protein sources including corn products, cottonseed meal, alfalfa meal and canola, amongst others in fish feeds have been promising. Advantages of plant protein sources can include lower price, greater availability and improved consistency of composition. Compared to fish meal, though they vary in their nutritional and biological values and generally have lower palatability. Deficiencies of EAA often cause decreases in growth performance and feed efficiency ratios (Anderson et al., 1995). Locations, seasonal changes, growth conditions, agricultural practices as well as variations between individual plants can affect the nutritional composition of plant materials (Harnly et al., 2009). Another limiting factor to using plant-derived proteins is the presence of ANF (anti nutritional factors) or toxicants that may be present as protease inhibitors, lectins, phytic acid, saponins, phytoestrogens, alkaloids, tannins, cyanogens and glucosinolates (Murray et al., 2010). ANF can adversely affect digestion, absorption and physiological utilization of protein and amino acids and can limit the palatability and the nutritive utilization of protein (Burel et al., 1998; Murray et al., 2010). Numerous ANF can be inactivated or reduced by heat treatment (Francis et al., 2001), dehulling, 
germination and other processing steps (Bau et al., 1997; El-Adawy, 2002; Kuo et al., 2004). Corn products are very promising due to the absence of ANF and high availability, although there are some nutritional limitations.

Soybean Meal (SBM): Soybean meal is produced by removing oil from whole soybeans, toasting the flakes then grinding into meal (AgMRC, 2010). Nutrient composition commonly ranges from $46.9-51.2 \%(\mathrm{db})$ CP, $1.5-4.7 \%(\mathrm{db})$ crude fat, $7.1-8.4 \%(\mathrm{db})$ crude fiber and $6.1-7.4 \%(\mathrm{db})$ ash. In addition, lysine content is generally $2.8-4.0 \%(\mathrm{db})$ and methionine is $0.5-0.9 \%(\mathrm{db})$ both of these concentrations are lower than found in fish meal (Table 4 and 5). In aquafeeds, SBM is the most commonly used plant protein because of its high availability, nutritional value, consistent composition and reasonable price (Refstie et al., 2000; Thompson et al., 2008). Factors which can limit the value of SBM in fish feed include Antinutritional Factors (ANF) such as protease inhibitors, trypsin inhibitors, phytates, lectins, phytic acid, saponins, phytoestrogens, antivitamins and allergens. Heat treatment can reduce the trypsin inhibitors but it has to be conducted with care due to possible reduction of nutritional value caused by overheating which can lead to the destruction of lysine, denaturation of protein and thus reduction in protein quality and digestibility (Francis et al., 2001; Barrows et al., 2007). Global SBM production has increased steadily over the last several decades and was estimated at 152.2 million ton for 2008/2009, compared to a production of 90.1 million ton in 1996/1997 (USDA, 2010b). Average SBM price for $2004 / 05$ was $\$ 205$ ton $^{-1}$, compared to an average price of $\$ 365$ ton $^{-1}$ in 2008/09 (USDA, 201 0a). Several studies have reported that the total replacement of fish meal with SBM has resulted in low palatability, reduction of nutrient digestibility and reduced growth (Thompson et al., 2007) and should be supplemented with methionine and/or lysine. Goda et al. (2007) concluded that dry extruded SBM and extruded full-fat soybean supplemented with lysine and methionine could effectively be used as the main source of dietary protein in a $28 \%$ CP diet fed to Nile tilapia fingerlings. In the same study, tilapia galilae (Sarotherodon galilaeus) fingerlings showed higher growth rate, weight gain and feed intake when fed the extruded SBM diet compared to the fish meal control diet. Furthermore, they assumed that high growth performance and feed utilization could be

Table 5: Proximate composition for various plant protien sources $(\%, \mathrm{db})^{*}$

\begin{tabular}{|c|c|c|c|c|c|c|c|}
\hline $\begin{array}{l}\text { Plant protien } \\
\text { sources }\end{array}$ & Crude protien & Crude fat & Crude fiber & NDF & $\mathrm{ADF}$ & Ash & References \\
\hline SBM & $46.9-51.2$ & $1.5-4.7$ & $7.1-8.4$ & $12.6-13.5$ & 8.8 & $6.1-7.4$ & $\begin{array}{l}\text { Cervantes-Prahm and Stein (2008), Abimorad et al. (2008), } \\
\text { Guimaraes et al. (2008), Glencross et al. (2005), Caine et al. (2008) } \\
\text { and Liu et al. (2009) }\end{array}$ \\
\hline SPC & $59.0-74.5$ & $0.3-5.4$ & 3.1 & 10.3 & NA & $5.5-7.9$ & $\begin{array}{l}\text { Glencross et al. (2005), Tibbetts et al. (2006), } \\
\text { Cervantes-Prahm and Stein (2008) and Cruz-Suarez et al. (2009) }\end{array}$ \\
\hline SPI & $88.5-92.6$ & $0.1-4.8$ & 0.4 & NA & NA & $4.7-6.5$ & $\begin{array}{l}\text { Glencross et al. (2005), Tibbetts et al. (2006) and } \\
\text { Cruz-Suarez et al. (2009) }\end{array}$ \\
\hline CGM & $66.7-74.7$ & $4.8-9.5$ & $0.8-2.4$ & $10.4-12.6$ & $5.6-6.9$ & $1.1-2.2$ & $\begin{array}{l}\text { Tibbetts et al. (2006), Abimorad et al. (2008), Guimaraes et al. (2008) } \\
\text { and Ingredients101 (2010e) }\end{array}$ \\
\hline CGF & $18.0-23.8$ & $3.5-3.9$ & $7.5-8.0$ & $33.8-45.0$ & $8.8-13.0$ & $6.1-6.8$ & $\begin{array}{l}\text { NRC (2001), Sauvant (2004), My er and Hersom (2008) and } \\
\text { Ingredients101 (2010f) }\end{array}$ \\
\hline DDGS & $26.8-33.7$ & $3.5-12.8$ & $5.4-10.6$ & $25.0-51.3$ & $8.0-23.6$ & $2.0-9.8$ & $\begin{array}{l}\text { NRC (2001), Rosentrater and Muthukumarappan (2006) and } \\
\text { Stein et al. (2006) }\end{array}$ \\
\hline CSM & $33.4-47.0$ & $1.6-4.5$ & $13.0-28.6$ & $23.9-35.3$ & $17.5-24.6$ & $5.7-7.8$ & $\begin{array}{l}\text { Cheng and Hardy (2002), Sauvant (2004), } \\
\text { Guimaraes et al. (2008) and Ingredients101 (2010c) }\end{array}$ \\
\hline Alfaalfa meal & 1 18.0-19.2 & 2.7 & $25.7-28.8$ & $41.6-48.0$ & $32.8-36.8$ & $10.4-11$ & NRC (2001), Ali et al. (2003) and Fekete et al. (2004) \\
\hline RSM/Canola & $33.7-43.1$ & 4.8 & $11.5-12.4$ & $28.3-29.8$ & $19.6-20.5$ & $6.5-7.9$ & $\begin{array}{l}\text { Sosulski and Zadernowski (1981), Burel et al. }(2000) \text {, } \\
\text { NRC (2001), Sauvant (2004) and Caine et al. (2008) }\end{array}$ \\
\hline Lupin meal & $34.1-48.2$ & $5.5-6.2$ & $11.6-19.0$ & $21.6-30.7$ & $16.2-27.6$ & $2.8-4.9$ & $\begin{array}{l}\text { Allan et al. (2000), Booth et al. (2001), Mariscal-Landin et al. (2002), } \\
\text { Sujak et al. (2006) and Pisarikova et al. (2008) }\end{array}$ \\
\hline Pea meal & $22.4-30.7$ & $1.1-2.6$ & 4.4-11.8 & $13.3-21.3$ & $6.9-14.5$ & $3.0-3.9$ & $\begin{array}{l}\text { Mariscal-Landin et al. (2002), Sauvant (2004), Caine et al. (2008) } \\
\text { and Khattab et al. (2009) }\end{array}$ \\
\hline Lentil meal & $25.9-33.1$ & $1.0-3.6$ & $1.2-7.5$ & $8.1-9.0$ & $5.4-6.0$ & $2.6-4.3$ & $\begin{array}{l}\text { Candela et al. (1997), Bednar et al. (2001), Wang and Daun (2006), } \\
\text { Wang et al. (2009) and El-Adaway et al. (2003) }\end{array}$ \\
\hline $\begin{array}{l}\text { Chickpea } \\
\text { meal }\end{array}$ & $21.0-24.0$ & 4.7-5.2 & $3.9-9.1$ & $10.9-16.9$ & $5.8-13.4$ & $2.7-3.6$ & $\begin{array}{l}\text { Abreu and Bruno-Soares (1998), Booth et al. (2001) } \\
\text { and Iqbal et al. (2006) }\end{array}$ \\
\hline Navy bean & $22.8-30.4$ & 1.6 & $5.6-8.1$ & $22.2-25.8$ & $6.7-9.9$ & $3.5-5.6$ & $\begin{array}{l}\text { Meiners et al. (1976), Paduano et al. (1995), Gyori et al. (1998), } \\
\text { Bednar et al. (2001), Hoover and Ratnayake (2002) and Feedstuff (2010) }\end{array}$ \\
\hline Pinto bean & $21.6-22.4$ & $0.8-1.0$ & $5.0-7.4$ & NA & 6.7 & $3.8-5.0$ & Meineres et al. (1976), Sotelo et al. (1995) and Wang et al. (2010b) \\
\hline Black bean & $23.2-25.9$ & $1.6-3.6$ & $3.3-3.5$ & NA & NA & $4.2-5.0$ & $\begin{array}{l}\text { Berrios et al. (1999), Bednar et al. (2001), Siddiq et al. (2010) and } \\
\text { Wang et al. (2010b) }\end{array}$ \\
\hline
\end{tabular}

*All data were reported on a dry matter basis; SBM: Soybean Meal; SPC: Soy Protien Concentrate; SPI: Soy Protien Isolate; CGM: Corn Gluten Meal; CGF: Com Gluten Feed; DDGS: Distillers Dried Grains with Solubles; CSM: Cottonseed Meal; RSM: Rapeseed Meal; NDF: Neutral Detergent Fiber; ADF: Acid Detergent Fiber; NA: Not Available 
ascribed to inactivation of heat-labile ANF in SBM via extrusion. Other studies also concluded that dehulled solvent-extracted and expeller-pressed SBM at 64 and $68 \%$ inclusion levels, respectively could totally replace fish meal in commercial diets containing 32\% protein for juvenile tilapia without methionine or lysine supplementation and without affecting weight gain, survival rate or palatability (Nguyen et al., 2009). In studies of Southern catfish (Silurus meridionalis) 39\% of the fish meal could be replaced with $23 \%$ SBM inclusion level without adversely affecting specific growth rate in a $48 \%$ CP diet; the researcher determined that reduced growth in diets containing high levels of SBM were due to imbalances of EAA such as methionine and could be improved by supplementation of methionine (Ai and Xie, 2005). Much research has been conducted for rainbow trout where SBM supplemented with or without lysine and methionine could replace $20-50 \%$ of the fish meal without compromising growth performance or weight gain (Oliva-Teles et al., 1994; Refstie et al., 2000). Barrows et al. (2007) came to similar conclusions when determining that extrusion of solvent-extracted SBM resulted in higher weight gain and feed intake when fed to rainbow trout. Dehulled and solvent-extracted SBM at $27 \%$ inclusion level supplemented with methionine replaced at least $33 \%$ of fish meal in a $37 \%$ CP Atlantic salmon diet (Carter and Hauler, 2000). Compared to rainbow trout, Atlantic salmon seems to be more sensitive to ANF in defatted SBM; in contrast to trout, they were not able to grow at a similar rate when fed diets with defatted SBM substituted for $37 \%$ of the dietary protein compared to when fed fish meal-based diets (Refstie et al., 2000). Defatting, dehulling, solvent-extracting, expeller pressing or fermenting can be applied to SBM to remove $\mathrm{ANF}$ and/or to improve the nutritive value. Investigations on SBM processed with or without amino acids resulted in successful total replacement of fish meal in diets for commercially important species such as Nile tilapia (Furuya et al., 2004; Ngyuen et al., 2009).

Soy Protein Concentrate (SPC): Soy protein concentrate is one of the three major soy protein products that is used in aquafeeds (Wang and Johnson, 2001). SPC is derived from dehulled, solvent-extracted, defatted flakes which are then extracted with ethanol or other acids so that soluble carbohydrates and various ANF are removed (Lusas and Riaz, 1995; USSEC, 2010). With a CP of 59.0-74.5\% (db), it has a CP content similar to fish meal. Crude fat is $0.3-5.4 \%$ (db), crude fiber is $3.1 \%(\mathrm{db})$ and ash is $5.5-7.9 \%(\mathrm{db})$. SPC is low in lysine with levels of $2.8-4.7 \%(\mathrm{db})$; methionine is low also ranging from $0.9-1.0 \%(\mathrm{db})$, thus these are limiting amino acids (Table 4 and 5). SPC has been used to replace fish meal in feed for salmonids (Carter and Hauler, 2000 ). Studies at $58 \%$ SPC inclusion level supplemented with lysine, methionine and taurine in a $46 \% \mathrm{CP}$ diet showed that yellowtail (Seriola quinqueradiata) juveniles had comparable growth to fish fed a fish meal-based diet (Takagi et al., 2008). SPC at 49\% inclusion level substituted up to $75 \%$ fish meal in $46 \%$ CP diets for juvenile cobia (Rachycentron canadum) without negatively affecting weight gain or growth rate (Salze et al., 2010). Furthermore, it was also possible to totally replace fish meal for juvenile rainbow trout with methionine supplemented SPC at $62 \%$ inclusion level in a $46 \%$ CP diet without reducing growth or nutrient utilization (Kaushik et al., 1995).

Soy Protein Isolate (SPI): Soy protein isolate is the purest commercially available soy protein product and has the highest protein content of all soy products. It is made from SPC by further processing to remove insoluble fiber using alkaline extraction and soluble sugars via acid precipitation (Wang and Johnson, 2001; Swain et al., 2004). Crude protein content is $88.5-92.6 \%(\mathrm{db})$, crude fat is $0.1-4.8 \%(\mathrm{db})$, crude fiber is $<0.4 \%(\mathrm{db})$ and ash is $4.7-6.5$. Lysine is $4.5-5.7 \%(\mathrm{db})$ and methionine is $1.1-1.3 \%(\mathrm{db})$ (Table 5 and 6). In recent years, SPE has been gaining attention in aquafeeds. In $45 \% \mathrm{CP}$ diets for juvenile cobia, SPI at $23 \%$ inclusion level substituted for $41 \%$ of fish meal and resulted in higher growth rate and weight gain compared to the fish meal-based control diet (Lunger et al., 2007).

On the other hand, when fed to post-juvenile Chinook salmon (Oncorhynchus tshawytscha) at 15 and $30 \%$ inclusion levels, digestibility of SPI could not be validated due to poor palatability (Hajen et al., 1993).

Corn Gluten Meal (CGM): Corn gluten meal is a coproduct of corn wet-mill processing which separates corn into starch, germ, protein and fiber fractions. It is the product remaining after the extraction of starch from the corn kernel (Goda et al., 2007) and consists predominantly of gluten (Sauvant, 2004). CGM has traditionally been used as cattle, swine and poultry feed (Wu et al., 1996). Crude protein content is high at $66.7-74.7 \%(\mathrm{db})$, crude fat is $4.8-9.5 \%(\mathrm{db})$, crude fiber is $0.8-2.4 \%(\mathrm{db})$ and ash is $1.1-2.2 \%(\mathrm{db})$. CGM is low in lysine, ranging from $1.0-2.1 \%(\mathrm{db})$ and low in methionine, ranging from $0.9-1.8 \%(\mathrm{db}$ ) (Table 5 and 6). CGM does not contain ANF. Average prices for CGM (containing 60\% CP), increased from $\$ 299-\$ 539$ ton $^{-1}$ from $2004 / 05$ to $2008 / 09$ for the Midwestern USA (USDA, 2010a). Several studies have examined CGM as a protein substitute in diets for fish. Nile tilapia have been fed up to $18 \%$ CGM inclusion 


\begin{tabular}{|c|c|c|c|c|c|c|c|c|c|c|c|}
\hline $\begin{array}{l}\text { Plant protien } \\
\text { sources }\end{array}$ & Arg & His & lle & Leu & $\begin{array}{l}\text { Lys } \\
-(\%)-- \\
\end{array}$ & Met & Phe & Thr & $\operatorname{Trp}$ & Val & References \\
\hline SBM & $3.2-4.2$ & $1.2-1.4$ & $2.0-2.3$ & $3.7-4.4$ & $2.8-4.0$ & $0.5-0.9$ & $2.3-2.4$ & $1.7-2.4$ & $0.5-0.6$ & $2.2-2.5$ & $\begin{array}{l}\text { Glencross et al. }(2005) \text {, } \\
\text { Guimaraes et al. (2008) and } \\
\text { Cervantes-Prahm and Stein (2008) }\end{array}$ \\
\hline SPC & $4.5-6.4$ & $1.5-2.0$ & $2.6-3.7$ & $4.7-5.9$ & $2.8-4.7$ & $0.9-1.0$ & $3.0-3.6$ & $2.5-3.1$ & $0.9-1.0$ & $2.7-3.8$ & $\begin{array}{l}\text { NRC (1998), Glencross et al. (2005) } \\
\text { and Cervantes-Prahm and Stein (2008) }\end{array}$ \\
\hline SPI & $6.7-7.5$ & $2.2-2.4$ & $3.8-4.6$ & $6.8-7.2$ & $4.5-5.7$ & $1.1-1.3$ & $4.5-4.7$ & $3.1-3.6$ & 1.1 & $4.0-4.6$ & NRC (1998) and Glencross et al. (2005) \\
\hline CGM & $1.9-2.2$ & $1.1-1.4$ & $2.0-2.8$ & $9.7-11.2$ & $1.0-2.1$ & $0.9-1.8$ & $3.3-4.4$ & $1.7-2.3$ & $0.3-0.5$ & $2.4-3.4$ & $\begin{array}{l}\text { NRC (1993), Guimaraes et al. (2008) } \\
\text { and Abemorad et al. (2008) }\end{array}$ \\
\hline CGF & $0.9-1.2$ & $0.6-0.7$ & $0.6-0.7$ & $1.6-2.2$ & $0.6-0.7$ & $0.3-0.5$ & $0.7-0.8$ & $0.7-0.8$ & $0.1-0.2$ & $0.9-1.1$ & $\begin{array}{l}\text { Schroeder (1997), NRC (1998) and } \\
\text { Sauvant (2004) }\end{array}$ \\
\hline DDGS & $0.9-2.2$ & $0.6-1.0$ & $0.9-1.5$ & $2.4-4.0$ & $0.5-1.1$ & $0.5-0.8$ & $1.3-1.7$ & $0.8-1.3$ & $0.2-0.3$ & $1.3-1.8$ & $\begin{array}{l}\text { NRC (1993), Stein et al. (2006) and } \\
\text { Rosentrater and Muthukumarappan (2006) }\end{array}$ \\
\hline CSM & $0.9-5.7$ & $0.5-1.4$ & $1.2-2.4$ & $1.0-2.8$ & $1.0-2.2$ & $0.5-1.1$ & $1.6-3.3$ & $0.9-1.7$ & $0.3-0.6$ & $1.4-2.9$ & $\begin{array}{l}\text { NRC (1998), Cheng and Hardy (2002) } \\
\text { and Guimaraes et al. (2008) }\end{array}$ \\
\hline Alfaalfa meal & $0.6-1.1$ & $0.3-0.5$ & $0.7-1.1$ & $1.2-1.6$ & $0.6-1.0$ & $0.3-0.4$ & $0.7-1.1$ & $0.6-0.9$ & $0.3-0.5$ & $0.9-1.3$ & $\begin{array}{l}\text { NRC (1998), Ali et al. (2003) and } \\
\text { Batal and Dale (2009) }\end{array}$ \\
\hline RSM/Canola & $1.1-2.5$ & $0.5-1.2$ & $0.8-1.8$ & $1.2-2.9$ & $1.2-2.5$ & $0.4-0.8$ & $0.7-1.6$ & $0.9-1.8$ & $0.3-0.5$ & $1.0-2.2$ & $\begin{array}{l}\text { NRC (1993), Fan and Sauer (1995) } \\
\text { and Sauvant (2004) }\end{array}$ \\
\hline Lupin meal & $3.8-4.4$ & $0.9-1.2$ & $1.4-1.7$ & $2.3-2.8$ & $1.4-2.1$ & $0.2-0.4$ & $1.3-1.4$ & $1.3-1.5$ & 0.3 & $1.3-1.6$ & $\begin{array}{l}\text { NRC (1998), Allen et al. (2000), } \\
\text { Booth et al. (2001) and } \\
\text { Pisarikova et al. (2008) }\end{array}$ \\
\hline Pea meal & $1.5-2.5$ & $0.5-0.6$ & $0.9-1.1$ & $1.5-1.7$ & $1.5-1.7$ & $0.2-0.3$ & $1.0-1.1$ & $0.8-0.9$ & 0.2 & $1.0-1.2$ & $\begin{array}{l}\text { NRC (1998), Allen et al. }(2000) \text {, } \\
\text { Booth et al. (2001) and } \\
\text { Sauvant (2004) }\end{array}$ \\
\hline Lentil meal & 2.3 & 0.9 & 1.1 & 2.1 & $1.6-1.9$ & 0.2 & 1.4 & 0.9 & 0.2 & 1. & NRC (1998) \\
\hline $\begin{array}{l}\text { Chickpea } \\
\text { meal }\end{array}$ & $1.5-2.0$ & $0.2-1.1$ & $0.8-1.1$ & $1.1-2.2$ & $1.4-1.8$ & $0.2-1.0$ & $1.1-1.5$ & $0.7-1.0$ & 0.2 & $0.8-1.3$ & $\begin{array}{l}\text { Allan } \text { et al. (2000), Booth et al. (2001), } \\
\text { Sauvant (2004) and Brenes et al. (2008) }\end{array}$ \\
\hline Navy bean & 6.9 & 7.1 & 2.1 & 6.5 & 6.0 & 1.1 & 3.9 & 3.4 & NA & 3.3 & Gyori et al. (1998) \\
\hline Pinto bean & 6.4 & 2.8 & 4.4 & 8.1 & 6.9 & 1.1 & 5.4 & 4.0 & 0.9 & 5.0 & Savoie \\
\hline Black bean & $5.5-6.7$ & $1.9-2.9$ & 4.1-4.3 & 7.7-8.6 & $6.7-7.1$ & $2.0-2.7$ & $5.1-5.8$ & 3.1-4.4 & $1.4-1.5$ & 4.9-5.1 & $\begin{array}{l}\text { Evans and Bandemer (1967) and } \\
\text { Hernandez et al. }(2008)\end{array}$ \\
\hline
\end{tabular}

*All data were reported on a dry matter basis; SBM: Soybean Meal; SPC: Soy Protien Concentrate; SPI: Soy Protien Isolate; CGM: Corn Gluten Meal; CGF: Corn Gluten Feed; DDGS: Distillers Dried Grains with Solubles; CSM: Cottonseed Meal; RSM: Rapeseed Meal

level in a $36 \% \mathrm{CP}$, non-fish meal diet (Wu et al., 1995). For turbot (Psetta maximal), CGM at 20\% inclusion level substituted for $40 \%$ of the fish meal in a $49 \%$ CP diet (Regost et al., 1999). For gilthead sea bream juveniles, CGM replaced up to $30 \%$ of the fish meal, at a $16 \%$ inclusion level, in a 43\% CP diet (Robaina et al., 1997) and $60 \%$ of the fish meal, at a $41 \%$ inclusion level, in a $48 \% \mathrm{CP}$ diet (Pereira and Oliva-Teles, 2003). For Japanese flounder juveniles, $40 \%$ of the fish meal was replaced by $29 \%$ CGM and $11 \%$ potato starch in a 56\% CP diet (Kikuchi, 1999).

Corn Gluten Feed (CGF): Corn gluten feed, similar to CGM is a coproduct of corn wet milling where the corn kernel is separated into starch, germ and fiber fractions (Wu et al., 1995). Compared to CGM, CGF also consists of bran, the steeping liquor and germ can be added as well (Sauvant, 2004). With a CP of $18.0-23.8 \%(\mathrm{db})$, CGF has a considerably lower CP content than CGM; it contains almost half the amount of crude fat of CGM $(3.5-3.9 \%, \mathrm{db})$. Crude fiber is $7.5-8.0 \%(\mathrm{db})$ which is considerably higher than CGM (up to 10 times the amount) which is expected due to the corn bran added to the CGF. Ash is 6.1-6.8\% (db) which is also lower than CGM. CGF is low in lysine $(0.6-0.7 \%, \mathrm{db})$ as well as methionine $(0.3-0.5 \%, \mathrm{db})$ (Table 5 and 6). The average price for CGF containing $21 \%$ protein for the Midwestern USA, increased from $\$ 57$ ton $^{-1}$ in $2004 / 05$ to $\$ 85$ ton $^{-1}$ in $2008 / 2009$ (USDA, 2010a). Traditionally, it has been used in livestock diets and pet foods (Robinson et al., 2001). CGF has also been used in aquafeeds. For example in a $35 \% \mathrm{CP}$ diet for Nile tilapia fry, $42 \%$ CGF and $51 \%$ soy flour were used as the sole protein source (i.e., no fish meal), this diet resulted in good but significantly lower, weight gain and feed conversion ratio than the control diet which contained fish meal; protein efficiency ratio was not significantly different from the control diet (Wu et al., 1996).

Channel catfish fingerlings (Ictalurus punctatus) were able to utilize CGF at inclusion levels up to $50 \%$ without adverse effects on palatability, weight gain or feed efficiency in a $32 \%$ CP diet when compared to a soybean meal-based, non-fish meal diet (Robinson et al., 2001).

Distillers Dried Grains with Solubles (DDGS): Distillers dried grains with solubles is the major coproduct of ethanol production which is mainly from corn grain in the USA and consists of $26.8-33.7 \%(\mathrm{db})$ crude protein, $3.5-12.8 \%(\mathrm{db})$ crude fat, $5.4-10.6 \%(\mathrm{db})$ crude fiber and $2.0-9.8 \%(\mathrm{db})$ ash. It is low in lysine with levels of $0.5-1.1 \%(\mathrm{db})$ and low in methionine with levels of $0.5-0.8 \%$ (db) (Table 5 and 6). As a result of the fermentation process, higher amounts of most nutrients 
are available compared to corn including protein, fat, fiber and minerals. In fact, levels of these nutrients are concentrated by approximately 3 times that of raw corn (Jacques et al., 2003). DDGS does not contain ANF which are commonly present in many other plant protein sources (Lim et al., 2009). The average price for DDGS in Indiana, USA was $\$ 84$ ton $^{-1}$ in 2004/05, $\$ 129$ ton $^{-1}$ in 2008/09 and $\$ 200$ ton $^{-1}$ in 2011 (USDA, 2010a). A continued increase in ethanol production due to changes in national energy policies will generate higher quantities of DDGS over time. Hence in the near future, prices are expected to decrease compared to SBM (Bals et al., 2006). Corn-based DDGS has historically been used for cattle (both beef and dairy) feed due to its high amounts of protein and fiber (Bals et al., 2006). Its use in fish diets has been limited, however due to low levels of EAA, particularly lysine and methionine (Table 6) as well as high fiber levels. However, compared to other protein sources such as SBM, DDGS is competitive on a per unit protein basis and is highly palatable to fish (Lim et al., 2009). Since the late 1940 's, DDGS has been incorporated at low inclusion levels in many fish feeds (Thompson et al., 2008). In numerous studies, DDGS has been used as a potential protein substitute for species such as Nile tilapia where $35 \%$ DDGS in combination with $58 \%$ soy flour could be incorporated in a $40 \% \mathrm{CP}$ diet, replacing fish meal without affecting growth performance or feed conversation ratios (Wu et al., 1996). Similar results for Nile tilapia were achieved where DDGS was included up to $20 \%$ in a $32 \%$ CP diet (Lim et al., 2007). In a 30\% CP diet for hybrid tilapia, DDGS at a $30 \%$ inclusion level, combined with other non-fish meal sources, totally replaced fish meal without significant differences in weight gain, specific growth rate, feed conversation ratio or protein conversation ratio (Coyle et al., 2004). Several studies have also been conducted for channel catfish and have replaced SBM in combination with or without corn meal. DDGS could be integrated up to $30 \%$ in a $32 \%$ CP diet without impacting weight gain, body length, survival or organoleptic quality (Webster et al., 1993). DDGS inclusion levels between $30-40 \%$, supplemented with lysine in 28 and $31 \% \mathrm{CP}$ diets were feasible without adversely affecting fish performance (Robinson and $\mathrm{Li}$, 2008; Lim et al., 2009). For rainbow trout levels up to 15 and $22.5 \%$, DDGS were successfully incorporated without and with supplemental lysine and methionine, substituting for 50 and $75 \%$ of the fish meal, respectively without adverse effects on weight gain, feed conversation ratio or survival (Cheng and Hardy, 2004).

Cottonseed Meal (CSM): Cottonseed meal is a byproduct from the solvent extraction of oil from partially dehulled cottonseeds (Sauvant, 2004). It can be expeller or solvent-extracted of which the latter is the more commonly used method. Depending on the processing used, the fat content differs. CSM is a high protein supplement often used for cattle feed and has about $89 \%$ of the energy value of SBM with a protein content of nearly $44 \%$ (Ingredients 101, 2010c). CSM generally contains around $33.4-44.7 \%(\mathrm{db})$ crude protein, $1.6-4.5 \%(\mathrm{db})$ crude fat, $13.0-28.6 \%(\mathrm{db})$ crude fiber and $5.7-7.8 \%(\mathrm{db})$ ash. Like many other plant protein sources, it is low in lysine and methionine compared to fish meal with concentrations of $1.0-2.2 \%(\mathrm{db})$ and $0.5-1.1 \%(\mathrm{db})$, respectively (Table 5 and 6).

On a protein basis, CSM is generally priced competitively with soybean meal and could reduce feeding expenses by $10-20 \%$ when replacing SBM (Robinson and $\mathrm{Li}, 2008$ ). Prices for CSM were at $\$ 139$ ton $^{-1}$ for $2004 / 05$ and increased to $\$ 281$ ton $^{-1}$ in 2008/09 (FAS, 2010).

CSM does contain several ANF substances, however including phytic acid, phytoestrogens, antivitamins and cyclopropenois acid (Francis et al., 2001) as well as the toxic pigment gossypol (Robinson and Li, 1994; Francis et al., 2001). In contrast to other non-ruminant animals such as poultry and swine, fish can tolerate higher amounts of gossypol (Cheng and Hardy, 2002). But limiting factors of CSM are the partial unavailability of lysine (Robinson and Li, 2008) and methionine as well as high concentrations of fiber (Cheng and Hardy, 2002). Thus, lysine and methionine are generally supplemented when using high concentrations of CSM in fish diets (Cheng and Hardy, 2002; Robinson and Li, 2008). CSM has been used in several fish feeding trials. In 29 and $32 \%$ CP diets for catfish, CSM supplemented with lysine could be included at levels of $>30 \%$ to replace 50 and $60 \%$ SBM, respectively without adverse effects on fish performance (Robinson and Li, 1994, 2008). When adding iron at a ratio of 1:1 to free gossypol in $33 \%$ CP juv enile Nile tilapia diets supplemented with lysine and methionine, CSM at 67\% inclusion level with other non-fish meal sources could totally replace fish meal without detrimental effects on growth performance and feed utilization (El-Saidy and Gaber, 2004). Studies in feed formulations for rainbow trout showed that CSM could be incorporated up to $10 \%$, substituting for $60 \%$ of the fish meal in a $44 \%$ CP diet without significant differences in weight gain, feed conversion ratio or survival (Cheng and Hardy, 2002).

Alfalfa meal: Alfalfa is the most important and widely grown forage legume and is called the queen of forages because of its nutritional quality and high biomass production (Ali et al., 2003; Yang et al., 2008). It is a low cost, widely used animal feed (Yanar et al., 2008). Generally, CP is $18.0-19.2 \%$ (db), crude fat is $2.7 \%$ (db), 
crude fiber is $25.7-28.8 \%(\mathrm{db})$ and ash is $10.4-11.0 \%(\mathrm{db})$. It is low in lysine and methionine with $0.6-1.0 \%(\mathrm{db})$ and $0.3-0.4 \%(\mathrm{db})$, respectively when compared to fish meal (Table 5 and 6 ). The average price for dehydrated alfalfa meal in 2004/05 was $\$ 142$ ton $^{-1}$ and rose to $\$ 260$ ton $^{-1}$ in 2008/09 (USDA, 2010a). Several studies have examined the use of alfalfa meal in Nile tilapia diets as a substitute for fish meal. Ali et al. (2003) concluded that alfalfa meal could be included only up to $5 \%$ in a $36 \%$ CP diet without reducing growth performance. The researchers assumed that high fiber levels and ANF were the reasons for growth depression and poor nutrient utilization. Likewise, Yousif et al. (1994) did not recommend the use of crude alfalfa for Nile tilapia diets, due to growth depression and decreasing feed utilization efficiency at inclusion levels between $5-30 \%$ in $41 \% \mathrm{CP}$ diets. The researcher assumed that the presence of ANF and imbalances in the amino acid profile were responsible for these unwanted effects. ANF of alfalfa meal can include protease inhibitors, saponins, phytoestrogens and antivitamins (Francis et al., 2001 ). On the other hand, purified alfalfa leaf protein concentrate could be included up to $26 \%$ in a $45 \%$ CP diet for tilapia, replacing $35 \%$ of the fish meal without negative growth performance (Olvera et al., 1990).

Canola/Rapeseed Meal (RSM): Rapeseed belongs to the genus Brassica and includes several species such as Brassica napus, Brassica campestris and Brassica juncea these are all closely related and similar in appearance. Traditional varieties of rapeseed contain high amounts of erucic acid whereas newer Canadian varieties (known as canola) contain lower values that were achieved by genetic modification. Therefore, canola and rapeseed are two different species (Shahidi, 1990). Furthermore, canola is a registered trademark of the Canadian Canola Association and refers to cultivars containing $<2 \%$ erucic acid (Raymer, 2002). In 2008/09, canola meal had a global production of 30.8 million ton and was the second largest protein meal produced after SBM (which yielded a global production of 151.6 million ton) (USDA, 2010c). The average world price for canola meal reached a value of $\$ 195$ ton $^{-1}$ in 2008/09, compared to $\$ 131$ ton $^{-1}$ in 2004/05 (FAS, 2010). Canola/Rapeseed (Brassica napus) meal is a byproduct obtained from solvent extraction of rapeseed cake which remains after processing rapeseed to remove the oil (Lardy and Kerley, 1994). With a CP content of $33.7-43.1 \%(\mathrm{db})$, it is one of the most widely used protein sources in animal feed and it is also used as a fertilizer (Peterson and Hustrulid, 1998). Crude fat is $4.8 \%(\mathrm{db})$, crude fiber is $11.5-12.4 \%(\mathrm{db})$ most of which is derived from the hulls (Bell, 1984) and ash is $6.5-7.9 \%(\mathrm{db})$. As with many other plant protein sources, it is low in lysine $(0.6-1.0 \%, \mathrm{db})$ and low in methionine $(0.3-0.4 \%$, db) (Table 5 and 6). RSM does contain ANF such as tannins, sinapin and phytic acid that limit inclusion rates in fish diets. Processing strategies such as dehulling and thermal treatment can reduce the ANF (Burel et al., 2000). Davies et al. (1990) concluded that RSM could be included up to 15 in $38 \%$ CP tilapia (Oreochromis mossambicus, Peters) feeds and could replace SBM without reducing growth performance. Studies on the inclusion of $30 \%$ dehulled, solventextracted and 30\% dehulled, heat-treated RSM in combination with fish meal in practical diets for rainbow trout and turbot have shown that protein digestibility was similar to high quality fish meal whereas digestibility for turbot was significantly lower without thermal treatment for the $46 \% \mathrm{CP}$ diet for rainbow trout, $28 \%$ of fish meal replacement was possible whereas for the $52 \% \mathrm{CP}$ turbot diet, 30\% fish meal substitution was shown to be possible (Burel et al., 2000). On the other hand, both expeller-extracted and solvent-extracted canola meal could be included up to $60 \%$ in 30\% CP diets for juvenile red sea bream (Pagrus auratus, Paulin) substituting for 50\% fish meal without adverse effects on growth rate, feed performance or protein utilization (Glencross et al., 2004).

Lupin Seed Meal (LSM): Lupin consists of different species (Sirtori et al., 2004) are used as ingredients in livestock feeds. The main species commonly used in fish feeds are Lupinus angustifolius, Lupinus albus and Lupinus luteus (De la Higuera et al., 1988; Burel et al., 1998; Glencross et al., 2005). Lupin is a protein-rich legume (CP from $34.1-48.2 \%, \mathrm{db}$ ) with a high oil content (crude fat from $5.5-6.2 \%, \mathrm{db}$ ) and high crude fiber $(11.6-19.0 \%, \mathrm{db})$.

Ash is $2.8-4.9 \%(\mathrm{db})$, lysine is $1.4-2.1 \%(\mathrm{db})$ and methionine is low at $0.2-0.4 \%(\mathrm{db})$ (Table 5 and 6). Whole LSM contains approximately $16 \%$ (db) crude fiber whereas dehulled LSM has only around 3.7\% (db) (Chien and Chiu, 2003). Depending on the species, CP of dehulled extruded LSM is approximately $42-55 \%(\mathrm{db})$, compared to $32-38 \%(\mathrm{db})$ for whole LSM (Burel et al., 1998; Glencross et al., 2005; Burel et al., 2000; Chien and Chiu, 2003). Lysine and methionine content for dehulled and whole lupin is similar (Allan et al., 2000; Glencross et al., 2005; Glencross et al., 2007). Disadvantages of whole LSM are high fiber contents and antinutrients such as a-galactosides, trypsin inhibitor and inositol phosphates (Martinez-Villaluenga et al., 2006). However, ANF are mainly alkaloids that affect palatability and can be washed out using water (Robaina et al., 1995). Dehulling increases the nutritive value of LSM by reducing the fiber content (Davis et al., 2002; Chien and Chiu, 2003), increasing the 
$\mathrm{CP}$ content and decreasing the amount of carbohydrates without affecting the lipid level (Glencross et al., 2007). Nonetheless, Hughes (1988) determined that the nutritional value of lupin is not dependent on heat treatment when used as a replacement for full fat SBM in rainbow trout fingerling diets. The researchers concluded that when lupin was included up to $40 \%$ in the diets, weight gain was equal to and digestibility was higher than the diet using full fat SBM as the primary protein source. Other studies on rainbow trout diets likewise reported that heating LSM (Lupinus albus) did not improve nutritional quality of the diets. Supplemented with lysine and methionine, crude LSM at 44\% inclusion level replaced fish meal partially (up to $30 \%$ ) in a $45 \% \mathrm{CP}$ diet without detrimental effects on weight gain, protein efficiency or digestibility (De la Higuera et al., 1988). Examining dehulled LSM (Lupinus angustifolius) at 40\% inclusion levels in 44\% CP diets for juvenile rainbow trout showed that $49 \%$ of the fish meal could be replaced without significantly affecting growth performance or nutrient utilization (Farhangi and Carter, 2001). Burel et al. (1998) concluded that depending on the crop between 50 and $70 \%$ extruded lupin (Lupinus albus) could be incorporated in 40 and $44 \% \mathrm{CP}$ diets, replacing $>50$ and $76 \%$ of the fish meal, respectively without significant differences in growth performance. In $56 \% \mathrm{CP}$ diets for juvenile gilthead sea bream, LSM (Lupinus angustifolius) was included up to $30 \%$ without compromising weight gain, feed efficiency or protein efficiency ratio, replacing up to $30 \%$ of the total dietary protein. However, the researchers concluded that LSM level should not exceed $20 \%$ of total protein to avoid liver lipid deposition (Robaina et al., 1997).

Pea meal: Field pea (Pisum sativum) has long been used as a protein source in livestock feeds (Davies et al., 2002). Peas contain about $22.4-30.7 \%(\mathrm{db}) \mathrm{CP}, 1.1-2.6 \%(\mathrm{db})$ crude fat, $4.4-11.8 \%(\mathrm{db})$ crude fiber and $3.0-3.9 \%(\mathrm{db}) \mathrm{db}$ ash. Starch content is often near $50 \%(\mathrm{db})$. Lysine is about $1.5-1.7 \%(\mathrm{db})$ and methionine is very low from $0.2-0.3 \%(\mathrm{db})$ (Table 5 and 6). Extruded field pea has a protein content of $26 \%(\mathrm{db})$ and crude fat of $1.9 \%(\mathrm{db})$ (Adamidou et al., 2009). Air classification can concentrate the starch and protein fractions (Boye et al., 2010). Pea protein concentrates which are produced by air separation after dehulling can yield a protein content of nearly $49 \%(\mathrm{db})$ (Carter and Hauler, 2000), lysine of $6.2 \%$ (db) and methionine of $0.9 \%(\mathrm{db})$ (Sanchez-Lozano et al., 2009). The average price for dry peas was $\$ 249$ ton $^{-1}$ in 2009 , compared to $\$ 150$ ton $^{-1}$ in 2004 (USDA, 2010d). Pea meal contains a variety of ANF such as protease inhibitors, phytic acid, polyphenols, tannins, cyanogens and lectins (Francis et al., 2001). And given that the protein content of peas is relatively low and the starch content is high (Burel et al., 2000), certain species (such as salmonids) have shown limited digestibility for peas. Heat treatment with (e.g., extrusion) has led to more successful use in fish feed ingredients, though. In addition, dehulling can result in increased digestibility due to the decrease in fiber (Burel et al., 2000). Extruded pea protein concentrate at inclusion levels of 20 and $27 \%$ replaced 20 and $33 \%$, respectively of the fish meal in Atlantic salmon parr diets without detrimental effects on growth performance (Carter and Hauler, 2000; Overland et al., 2009). Inclusion of $25 \%$ dehulled peas and $20 \%$ air-classified pea protein replaced up to 78 and $61 \%$ soybean meal, respectively in 53\% CP diets for rainbow trout diets without significantly affecting feed intake and growth performance (Thiessen et al., 2003). Pea-derived meal at $40 \%$ inclusion replaced $18 \%$ fish meal in $48 \% \mathrm{CP}$ European sea bass fingerling diets without statistically significant differences in final weight or specific growth rate (Gouveia and Davies, 1998). In nutrient digestibility studies, extruded field peas could be included at $30 \%$ in $44 \% \mathrm{CP}$ diets for European sea bass and replaced up to $10 \%$ of the fish meal without significant differences in protein, fat, starch or energy digestibility (Adamidou et al., 2009).

For $44 \%$ CP juvenile gilthead sea bream diets, up to $20 \%$ fish meal was replaced with $35 \%$ dehulled, defibered, extruded pea meal and $37 \%$ infrared radiation-treated ground whole pea, respectively without compromising fish performance (Pereira and Oliva-Teles, 2002). In 30\% $\mathrm{CP}$ diets for juvenile milkfish (Chanos chanos Forsskal), ground peas at $10 \%$ inclusion level substituted for $20 \%$ SBM without adverse effects on weight gain, survival or body composition (Borlongan et al., 2003).

Lentil meal: Lentils are important leguminous seeds for many developing countries (Salunkhe and Kadam, 1989) and Lens culinaris are the most used and most studied lentil species (Rozan et al., 2001). They contain $25.9-33.1 \%$ (db) CP, $1.0-3.6 \%(\mathrm{db})$ crude fat, $1.2-7.5 \%$ (db) crude fiber, $2.6-4.3 \%(\mathrm{db})$ ash and are low in lysine $(1.6-1.9 \%, \mathrm{db})$ and methionine $(0.2 \%, \mathrm{db})$ (Table 5 and 6$)$. Average prices for lentils in 2009 were $\$ 573$ ton $^{-1}$, compared to $\$ 328$ ton $^{-1}$ in 2004 (USDA, 2010e). Like other legumes, lentils contain ANF such as trypsin inhibitors, tannins, polyphenols and phytates that limit their utilization (Vidal-Valverde et al., 1994). Dehulling and cooking lentils can result in significantly increased protein and starch levels and decrease tannins. Furthermore, cooking reduces phytic acid levels (Vidal-Valverde et al., 1994; Wang et al., 2009), germination lowers trypsin inhibitor activity, tannins and phytic acid and soaking 
decreases phytates and tannins. It is suggested to use $>1$ method to reduce ANF most effectively (Vidal-Valverde et al., 1994). Unfortunately, animal feeding trials with lentils have been limited. The only published study found on use of lentils in fish diets was on extruded red lentil (Lens culinaris L.) meal at 30\% inclusion, integrated into a $45 \% \mathrm{CP}$ diets for juvenile rainbow trout. These diets resulted in significantly lower weight gain, specific growth rate and digestibility values than the control diet when replacing $30 \%$ of the fish meal content. The researchers assumed that the lower growth rate was a result of the lower methionine content in the diet (Yagci et al., 2009). Likewise, feeding studies for rats (a monogastric animal) including whole lentil meal or dehulled lentil meal as the sole protein source resulted in significantly reduced growth and weight gain (Cuadrado et al., 2002).

Chickpea meal: Chickpeas (Cicer arietinum L.) also known as garbanzo beans have mainly been produced for human food. Crude protein is $21.0-24.0 \%(\mathrm{db})$, crude fat is $4.7-5.2 \%(\mathrm{db})$, crude fiber is $3.9-9.1 \%(\mathrm{db})$ and ash is $2.7-3.6 \%(\mathrm{db})$. Lysine and methionine are both low at $1.4-1.8 \%(\mathrm{db})$ and $0.2-1.0 \%(\mathrm{db})$, respectively (Table 5 and 6). Crude protein of dehulled or extruded chickpeas have been shown to be around 24 and $28 \% \mathrm{db}$, respectively and crude fat for both is approximately $5 \% \mathrm{db}$ (Booth et al., 2001; Adamidou et al., 2009). The average wholesale price for chickpeas in 2008/09 for Idaho, USA was $\$ 901$ ton $^{-1}$, compared to $\$ 856$ ton $^{-1}$ in 2004/05 (USDA, 2010f). Chickpeas contain several ANF including trypsin inhibitors, alpha-galactosides, saponins and tannins (Nestares et al., 1996; Salgado et al., 2001). Cooking or heat treating chickpeas can significantly decrease trypsin inhibitor activity levels (El-Adawy, 2002; Wang et al., 2010b). Studies on chickpeas in fish diets are limited but some research has been done with other animals including pigs (Mustafa et al., 2000), rats (Nestares et al., 1996; Rubio et al., 1998) and chickens (Christodoulou et al., 2006; Brenes et al., 2008). Diets with extruded chickpeas were shown to result in improved weight gain in growing chickens (Brenes et al., 2008).

In digestibility studies for European sea bass, extruded chickpea meal could be included up to $30 \%$ in a 44\% CP diet without adversely affecting protein, fat, starch or energy digestibility (Adamidou et al., 2009). Booth et al. (2001) suggested that chickpeas (Cicer arietinum-cv. Desi.) could be dehulled and refined to improve energy digestibility for use in juvenile silver perch diets. Furthermore, they concluded that dehulling yielded $>80 \%$ reduction in $\mathrm{ADF}$ and $>10 \%$ increase in protein although, it did not improve protein digestibility.
Common beans: Common bean (Phaseolus vulgaris L.) is a plant species which contains a wide range of genetic varieties such as navy, pinto and black beans. They are primarily used as human food and have low levels of fat and high levels of proteins, complex carbohydrates, vitamins and minerals (Anton et al., 2008). They are rich in lysine but deficient in methionine and contain ANF such as phytates, trypsin and chymotrypsin inhibitors (Reddy et al., 1985). Various ANF can be inactivated by proper heat treatment (Van Der Poel, 1990). Common beans have hardly been investigated as substitutes for fish meal and information about digestibility for fish diets is rare or not available.

However based on moderately high protein content, a lysine concentration similar to that of fish meal and relatively high availability, common beans could be a potential aquafeed ingredient when processed appropriately. On the other hand, high price, generally $>\$ 600$ ton $^{-1}$ in the USA must be considered a potential limiting factor. In one of the few studies, extruded common bean at a $30 \%$ inclusion level has been investigated in $45 \% \mathrm{CP}$ juvenile rainbow trout diets. There were no significant differences for weight gain, specific growth rate or digestibility among the fish fed the control diet when substituting for $30 \%$ of the fish meal (Yagci et al., 2009).

Navy (white) beans: Navy beans are widely produced for human food. Crude protein content is generally between $22.8-30.4 \%(\mathrm{db})$, crude fat is around $1.6 \%(\mathrm{db})$, crude fiber is $5.6-8.1 \%(\mathrm{db})$ and ash is approximately $3.5-5.6 \%(\mathrm{db})$. Lysine is around $6.0 \%(\mathrm{db})$ (which is similar to fish meal) whereas methionine is low at $1.1 \%(\mathrm{db})$ (Table 5 and 6). Cooked freeze-dried navy bean powder contains approximately $25 \%(\mathrm{db})$ crude protein, $5.2 \%(\mathrm{db})$ crude fiber and $2 \%(\mathrm{db})$ crude fat (Thompson et al., 2009).

The average wholesale price for dry navy beans in 2008/09 for Michigan, USA was $\$ 871$ ton $^{-1}$, compared to $\$ 653$ ton $^{-1}$ in $2004 / 05$ (USDA, 2010f). Navy beans contain high amounts of trypsin inhibitors, phytic acids (Anton et al., 2008; Martin-Cabrejas et al., 2009), chymotrypsin inhibitors (Martin-Cabrejas et al., 2009), lectins and protease inhibitors (Paduano et al., 1995; Martin-Cabrejas et al., 2009). After heat treatment, levels of trypsin inhibitors and phytic acids can be significantly reduced (Anton et al., 2008).

For other monogastric animals such as rats, poor growth has been observed when fed navy beans. On the other hand, growth improved after heat treatment (Kakade and Evans, 1966). When fed to sheep, navy beans were only suitable at low levels after heat treatment (Paduano et al., 1995). 
Pinto beans: Crude protein concentration of pinto beans is generally between $21.6-22.4 \%(\mathrm{db})$, crude fat is $0.8-1.0 \%(\mathrm{db})$, crude fiber is $5.0-7.4 \%(\mathrm{db})$ and ash is $3.5-3.8 \%(\mathrm{db})$ (Table 5 ). With lysine of approximately $6.9 \%(\mathrm{db})$, it appears to be an adequate source for lysine but it is low in methionine, at around $1.1 \%(\mathrm{db})$ when compared to fish meal. The average wholesale price for dry pinto beans in 2008/09 for Colorado, USA was $\$ 914$ ton $^{-1}$, compared to $\$ 782$ ton $^{-1}$ in 2004/05 (USDA, 2010f). As for other pulses, pinto beans contain trypsin inhibitors, phytic acids, tannins and oligosaccharides that limit protein and carbohydrate utilization. Cooking can significantly decrease trypsin inhibitor activity, tannins and sucrose (Wang et al., 2010b).

Black beans: Black beans have a crude protein content between $23.6-25.9 \%(\mathrm{db})$, crude fat of $1.6-3.3 \%(\mathrm{db})$ and ash of $4.2-4.7 \%$ (db) (Table 5). Again, cooking or heat treatment can significantly decrease the ANF (Wang et al., 2010b). Cooked freeze dried black bean powder contains approximately $27 \%(\mathrm{db})$ protein, $2 \%(\mathrm{db})$ crude fat and 5\% (db) crude fiber (Thompson et al., 2009). The average wholesale price for dry black beans in 2008/09 for Michigan, USA was $\$ 1030$ ton $^{-1}$, compared to $\$ 583$ ton $^{-1}$ in 2004/05 (USDA, 2010f).

\section{CONCLUSION}

Traditionally, commercial aquafeeds have been based on fish meal due to its many advantages, including high protein content, high digestibility, essential amino acid profile, fatty acid profile, minerals, vitamins and palatability. These characteristics make it very challenging to find less expensive alternatives to fish meal without affecting fish performance and fillet quality. Large amounts of unwanted nutrients such as fiber, ANF and other carbohydrates can limit inclusion levels of many plant protein sources even though the protein content might be adequate. Processing prior to use in the feed can enhance protein availability by reducing or inactivating heat-labile ANF such as trypsin inhibitors. Additionally, dehulling can reduce high levels of fiber and enhance the protein content. Furthermore, many plant protein sources lack EAA such as lysine and methionine but this can be compensated for by supplementation of these components. Limiting factors for animal byproducts also include cost-intensive processing as well as deficiencies or excesses of various EAA. Variations in nutrient composition and protein quality exists in both animal and plant protein sources, based on inconsistencies of the raw materials, seasonal changes, growth conditions, cultivation practices and differences in cultivars or species used, etc.
Since, fishery byproducts, particularly fish meals produced from fishery discard and processing waste are initially fish products, they appear to be the most adequate fish meal replacers. However, differences in quality have to be considered and depending on the source, removal of structural components such as chitin and bones may have to be accomplished to improve the nutritional value. In addition, the limited availability has to be considered. Nevertheless, other promising alternative protein sources could include animal byproducts such as meat and bone meal and poultry byproduct meal. The advantages of animal products include sufficient amounts of lysine and/or methionine, few ANF, sufficient quantities in the marketplace and substantially lower prices than fish meal. Potential plant protein sources can include soybean meal, soy protein concentrate, soy protein isolate, distillers dried grain with solubles, cottonseed meal, rapeseed/canola meal and lupin seed meal all of which can yield high fish meal replacement levels but they may require lysine and/or methionine supplementation. Due to relatively low prices and no ANF (which are commonly present in many plant sources), distillers dried grain with solubles and cottonseed meal appear to be attractive alternatives, particularly to higher priced SBM. On the other hand, common beans, corn gluten meal, chickpeas and lentils appear to be too high priced to be competitive with fish meal. Depending on the location of an aquaculture facility a sustainable strategy would be to use locally available plant sources in combination with animal protein sources such as rendered products, depending on what is available.

\section{RECOMMENDATIONS}

When using plant protein sources such as soybean, pea or lentil, it is recommended to dehull and to heat treat these materials to reduce fiber content, enhance protein content and remove ANF. The use of alternative plant or animal protein sources is still in its infancy. More research, particularly commercially-focused studies examining feed acceptability, digestibility, fillet quality and impacts on entire production costs have to be conducted to successfully replace fish meal completely. Promising solutions may be found with combinations of protein sources where one portion is animal based and the other is a plant based. Factors that should be considered are the regionality of products that may therefore be less expensive and more available (e.g., rendered products and crops that are planted regionally). These factors may not only contribute to more cost-efficient commercial fish production but may also lead to better protection of the environment, since transportation can be reduced. Additionally, this approach may add new jobs since, production and processing could be conducted 
regionally. Thus, the intention this effort is to use fish meal as an enhancing ingredient not as a primary protein source in aquafeeds. Depletion of oceans can be minimized and diversity of fish species can be protected of such strategies are adopted.

\section{ACKNOWLEDGEMENTS}

The researchers thank the Agricultural Experiment Station, South Dakota State University and the North Central Agricultural Research Laboratory, USDA-ARS, Brookings, South Dakota for funding, facilities, equipment and supplies. In addition, the valuable support of Kenneth Kalscheur who supplied part of the raw data and the assistance of Sharon Nichols is greatly appreciated.

\section{REFERENCES}

Aas, T.S., B. Grisdale-Helland, B.F. Terjesen and S.J. Helland, 2006a. Improved growth and nutrient utilisation in Atlantic salmon (Salmo salar) fed diets containing a bacterial protein meal. Aquaculture, 259: $365-376$.

Aas, T.S., B. Hatlen, B. Grisdale-Helland, B.F. Terjesen, A.M. Bakke-McKellep and S.J. Helland, 2006b. Effects of diets containing a bacterial protein meal on growth and feed utilisation in rainbow trout (Oncorhynchus mykiss). Aquaculture, 261: 357-368.

Aas, T.S., B. Hatlen, Grisdale-Helland, B.F. Terjesen, M. Penn, A.M. Bakke-McKellep and S.J. Helland, 2007. Feed intake, growth and nutrient utilization in Atlantic halibut (Hippoglossus hippoglossus) fed diets containing a bacterial protein meal. Aquaculture Res., 38: 351-360.

Abdel-Tawwab, M., M.H. Ahmad, Y.A.E. Khattab and A.M.E. Shalaby, 2010. Effect of dietary protein level, initial body weight and their interaction on the growth, feed utilization and physiological alterations of Nile tilapia, Oreochromis niloticus (L.). Aquaculture, 298: 267-274.

Abimorad, E.G., G.H. Squassoni and D.J. Carneiro, 2008. Apparent digestibility of protein, energy and amino acids in some selected feed ingredients for pacu Piaractus mesopotamicus. Aquaculture Nutrition, 14: 374-380.

Abreu, J.M.F. and A.M. Bruno-Soares, 1998. Chemical composition, organic matter digestibility and gas production of nine legume grains. Anim. Feed Sci. Technol., 70: 49-57.

Adamidou, S., I. Nengas, M. Henry, K. Grigorakis and G. Rigos, 2009. Growth, feed utilization, health and organoleptic characteristics of European seabass (Dicentrarchus labrax) fed extruded diets including low and high levels of three different legumes. Aquaculture, 293: 263-271.
AgMRC, 2010. Soyfood profile. Agricultural Marketing Resource Center, Lowa State University, Ames, IA., USA.

Ai, Q. and X. Xie, 2005. Effects of replacement of fish meal by soybean meal and supplementation of methionine in fish meal/soybean meal-based diets on growth performance of the Southern Catfish Silurus meridionalis. J. World Aquacult. Soc., 36: 498-507.

Al Hafedh, Y.S., A.Q. Siddiqui and M.Y. Al-Saiady, 1999. Effects of dietary protein levels on gonad maturation, size and age at first maturity, fecundity and growth of Nile Tilapia. Aquacult. Int., 7: 319-332.

Ali, A., N.A. Al-Asgah, S.M. Al-Ogaily and S. Ali, 2003. Effect of feeding different levels of Alfalfa meal on the growth performance and body composition of Nile Tilapia (Oreochromis niloticus) fingerlings. Asian Fisher. Sci., 16: 59-67.

Alibaba Group., 2010. Fish meal made from jack mackerel. http://www .alibaba.com/product-free/101377815/ Fish_Meal_Made_From_Jack_Mackerel.html.

Allan, G.L., S. Parkinson, M.A. Booth, D.A.J. Stone, S.J. Rowland, J. Frances and R. Warner-Smith, 2000. Replacement of fish meal in diets for Australian silver perch, Bidyanus bidyanus: I. Digestibility of alternative ingredients. Aquaculture, 186: 293-310.

Anderson, J., A.J. Jackson, A.J. Matty and B.S. Capper, 1984. Effects of dietary carbohydrate and fibre on the tilapia Oreochromis niloticus (L.). Aquaculture, 37: 303-314.

Anderson, J.S., S.P. Lall, D.M. Anderson and J. Chandrasoma, 1992. Apparent and true availability of amino acids from common feed ingredients for Atlantic salmon (Salmo salar) reared in sea water. Aquaculture, 108: 111-124.

Anderson, J.S., S.P. Lall, D.M. Anderson and M.A. McNiven, 1993. Evaluation of protein quality in fish meals by chemical and biological assays. Aquaculture, 115: 305-325.

Anderson, J.S., S.P. Lall, D.M. Anderson and M.A. McNiven, 1995. Availability of amino acids from various fish meals fed to Atlantic salmon (Salmo salar). Aquaculture, 138: 291-301.

Anton, A.A., K.A. Ross, O.M.R. Lukow, G. Fulcher and S.D. Arntfield, 2008. Influence of added bean flour (Phaseolus vulgaris L.) on some physical and nutritional properties of wheat Flour tortillas. Food Chem., 109: 33-41.

Bals, B., B. Dale and V. Balan, 2006. Enzymatic hydrolysis of distiller's dry grain and solubles (DDGS) using ammonia fiber expansion pretreatment. Energy Fuels, 20: 2732-2736. 
Banks, C.J. and Z. Wang, 2006. Treatment of Meat Wastes. In: Waste Treatment in the Food Processing Industry, Wang, L.K., Y.T. Hung, H.H. Lo and C. Yapijakis (Eds.). Taylor and Francis Group, Boca Raton, FL., USA., pp: 67-100.

Barrows, F.T., D.A.J. Stone and R.W. Hardy, 2007. The effects of extrusion conditions on the nutritional value of soybean meal for rainbow trout (Oncorhynchus mykiss). Aquaculture, 265: 244-252.

Batal, A. and N. Dale, 2009. Ingredient analysis table: 2010 edition. http://fdsmagissues. feedstuffs. com/ $\mathrm{fds} /$ Reference_issue_2010/Reference issue 2009/0 3 Ingredient $\% 20$ Analysis $\% 20$ Table $\% 202010 \% 20 \mathrm{E}$ dition.pdf.

Bau, H.M., C. Villaume, J.P. Nicolas and L. Mejean, 1997. Effect of germination on chemical composition, biochemical constituents and antinutritional factors of soya bean (Glycine max) seeds. J. Sci. Food Agric., 73: 1-9.

Bednar, G.E., A.R. Patil, S.M. Murray, C.M. Grieshop, N.R. Merchen and G.C. Jr. Fahey, 2001. Nutrient metabolism: Starch and fiber fractions in selected food and feed ingredients affect their small intestinal digestibility and fermentability and their large bowel fermentability in vitro in a canine model. J. Nutr., 131: $276-286$

Bell, M., 1984. Nutrients and toxicants in rapeseed meal: A review. J. Anim. Sci., 58: 996-1010.

Berrios, J.D.J., B.G. Swanson and W. Adeline Cheong, 1999. Physico-chemical characterization of stored black beans (Phaseolus vulgaris L.). Food Res. Int., 32: 669-676.

Bharadwaj, A.S., W.R. Brignon, N.L. Gould, P.B. Brown and V. Wu, 2002. Evaluation of meat and bone meal in practical diets fed to juvenile hybrid striped bass Morone chrysops x M. saxatilis. J. World Aquac. Soc., 33: 448-457.

Bishop, C.D., R.A. Angus and S.A. Watts, 1995. The use of feather meal as a replacement for fish meal in the diet of Oreochromis niloticus fry. Bioresour. Technol., 54: 291-295.

Booth, M.A., G.L. Allan, J. Frances and S. Parkinson, 2001. Replacement of fish meal in diets for Australian silver perch, Bidyanus bidyanus: IV. Effects of dehulling and protein concentration on digestibility of grain legumes. Aquaculture, 196: 67-85.

Borghesi, R., L. Portz, M. Oetterer and J.E.P. Cyrino, 2008. Apparent digestibility coefficient of protein and amino acids of acid, biological and enzymatic silage for Nile tilapia (Oreochromis niloticus). Aquac. Nutr., 14: $242-248$.
Borlongan, I.G., P. Eusebia and T. Welsh, 2003. Potential of feed pea (Pisum sativum) meal as a protein source in practical diets for milkfish (Chanos chanos Forsskal). Aquaculture, 225: 89-98.

Boye, J., F. Zare and A. Pletch, 2010. Pulse proteins: Processing, characterization, functional properties and applications in food and feed. Food Res. Int., 43: 414-431.

Brenes, A., A. Viveros, C. Centeno, I. Arija and F. Marzo, 2008. Nutritional value of raw and extruded chickpeas (Cicer arietinum L.) for growing chickens Spanish. J. Agric. Res., 6: 537-545.

Bureau, D.P., A.M. Harris and C.Y. Cho, 1999. Apparent digestibility of rendered animal protein ingredients for rainbow trout (Oncorhynchus mykiss) diets. Aquaculture, 180: 345-358.

Bureau, D.P., A.M. Harris, D.J. Bevan, L.A. Simmons, P.A. Azevedo and C.Y. Cho, 2000. Feather meals and meat and bone meals from different origins as protein sources in rainbow trout (Oncorhynchus mykiss) diets. Aquaculture, 181: 281-291

Burel, C., T. Boujard, F. Tulli and S.J. Kaushik, 2000. Digestibility of extruded peas, extruded lupin and rapeseed meal in rainbow trout (Oncorhynchus mykiss) and turbot (Psetta maxima). Aquaculture, 188: 285-298.

Burel, C., T. Boujard, G. Corrazze, S.J. Kaushik and G. Boeuf et al., 1998. Incorporation of high levels of extruded lupin in diets for rainbow trout (Oncorhynchus mykiss). Nutritional value and effect on thyroid status. Aquaculture, 163: 32-45.

Caine, W.R., W.C. Sauer, G.S. Huang, G. Diebold, M. Schollenberger and R. Mosenthin, 2008. Influence of guanidination on apparent ileal digestibility of amino acids in pigs fed diets with soybean meal, rapeseed meal or peas as a protein source. Livestock Sci., 116: $300-308$.

Candela, M., I. Astiasaran and J. Bello, 1997. Cooking and warm-holding: Effect on general composition and amino acids of kidney beans (Phaseolus vulgaris), chickpeas (Cicer arietinum) and lentils (Lens culinaris). J. Agric. Food Chem., 45: 4763-4767.

Carter, C.G. and R.C. Hauler, 2000. Fish meal replacement by plant meals in extruded feeds for Atlantic salmon, Salmo salar L. Aquaculture, 185: 299-311.

Cervantes-Prahm, S.K. and H.H. Stein, 2008. Effect of dietary soybean oil and soybean protein concentration on the concentration of digestible amino acids in soybean products fed to growing pigs. J. Anim. Sci., 86: 1841-1849. 
Chandler, N.J., 2009. Feather meal: Its nutritional value and use in dairy and beef rations. http: //en. eng ormix.com/MA-dairy-cattle/nutrition/articles/feathermeal-its-nutritional 79.htm.

Cheng, Z.J. and R.W. Hardy, 2002. Apparent digestibility coefficients of nutrients and nutritional value of poultry by-product meals for rainbow trout Oncorhynchus mykiss measured in vivo using settlement. J. World Aquac. Soc., 33: 458-465.

Cheng, Z.J. and R.W. Hardy, 2004. Nutritional value of diets containing distiller's dried grain with solubles for rainbow trout, Oncorhynchus mykiss. J. Applied Aquacult., 15: 101-113.

Chien, Y.H. and Y.H. Chiu, 2003. Replacement of soybean (Glycine max (L.) Merrill) meal by lupin (Lupinus angustifolius) seed meal in diet for juvenile tilapia (Oreochromis niloticus $\mathrm{x} O$. aureus) reared indoors. Aquacult. Res., 34: 1261-1268.

Chitmanat, C., A. Tipin, P. Chaibu and S. Traichaiyaporn, 2009. Effects of replacing fishmeal with wastes derived from local fisheries on the growth of juvenile tilapia, Oreochromis niloticus. Songklanakarin J. Sci. Technol., 31: 105-110.

Chou, B.S., S. Y. Shiau, 1996. Optimal dietary lipid level for growth of juvenile hybrid tilapia, Oreochromis niloticus $\mathrm{x}$ Oreochromis aureus. Aquacult, 143: 185-195.

Christodoulou, V., V.A. Bampidis, B. Hucko and Z. Mudrik, 2006. The use of extruded chickpeas in diets of broiler turkeys. Czech J. Anim. Sci., 51: 416-423.

Coyle, S.D., G.J. Mengel, J.H. Tidwell and C.D. Webster, 2004. Evaluation of growth, feed utilization and economics of hybrid tilapia, Oreochromis niloticus X Oreochromis aureus, fed diets containing different protein sources in combination with distillers dried grains with solubles. Aquac. Res., 35: $365-370$.

Cruz-Suarez, L.E., M. Tapia-Salazar, D. Villarreal-Cavazos, J. Beltran-Rocha, M.G. Nieto-Lopez, A. Lemme and D. Ricque-Marie, 2009. Apparent dry matter, energy, protein and amino acid digestibility of four soybean ingredients in white shrimp Litopenaeus vannamei juveniles. Aquaculture, 292: 87-94.

Cuadrado, C., G. Grant, L.A. Rubio, M. Muzquiz, S. Bardocz and A. Puszta, 2002. Nutritional utilization by the rat of diets based on lentil (Lens culinaris) seed meal or its fractions. J. Agric. Food Chem., 50: 437-4376.

Davies, S.J., S.S. McConnell and R.I. Bateson, 1990. Potential of rapeseed meal as an alternative protein source in complete diets for tilapia (Oreochromis mossambicus peters). Aquaculture, 87: 145-154.
Davis, D.A., C.A. Arnold and I. McCallum, 2002. Nutritional value of feed peas Pisum sativum in practical diet formulations for Litopenaeus vannamei. Aquac. Nutr., 8: 87-94.

De la Higuera, M., M. Garcia-Gallego, A. Sanz, G. Cardenete, M.D. Suarez and F.J. Moyano, 1988. Evaluation of lupin seed meal as an alternative protein source in feeding of rainbow trout Salmo gairdneri. Aquaculture, 71: 37-50.

Del Carmen Gonzalez-Pena, M., S.Z. Gomes and G.S. Moreira, 2002. Effects of dietary fiber on growth and gastric emptying time of the freshwater prawn Macrobrachium rosenbergii (De Man, 1879). J. World Aquacultu. Soc., 33: 44-447.

Dias, J., C. Huelvan, M.T. Dinis and R. Metailler, 1998. Influence of dietary bulk agents (silica, cellulose and a natural zeolite) on protein digestibility, growth, feed intake and feed transit time in European seabass (Dicentrarchus labrax) juveniles, Aquatic. Living Resources, 11: 219-226.

El-Adawy, T.A., 2002. Nutritional composition and antinutritional factors of chickpeas (Cicer arietinum L.) undergoing different cooking methods and germination. Plant Food Human Nutr., 57: 83-97.

El-Haroun, E.R., P.A. Azevedo and D.P. Bureau, 2009. High dietary incorporation levels of rendered animal protein ingredients on performance of rainbow trout Oncorhynchus mykiss (Walbaum, 1972). Aquaculture, 290: 269-274.

El-Saidy, D.M.S.D. and M.M.A. Gaber, 2002. Complete replacement of fish meal by soybean meal with dietary L-lysine supplementation for Nile tilapia Oreochromis niloticus (L.) fingerlings. J. World Aquacult. Soc., 33: 297-306.

El-Saidy, D.M.S.D. and M.M. Gaber, 2004. Use of cottonseed meal supplemented with iron for detoxification of gossypol as a total replacement of fish meal in Nile tilapia, Oreochromis niloticus (L.) diets. Aquacult. Res., 35: 859-865.

El-Sayed, A.F.M., 1998. Total replacement of fish meal with animal protein sources in Nile tilapia, Oreochromis niloticus (L.) feeds. Aquacult. Res., 29: 275-280.

FAO, 2009a. Fish and fishery products. http:/www.fao.org/docrep/011/ai482e/ai482e10.htm.

FAO, 2009b. State of World Fisheries and Aquaculture 2008. Food and Agriculture Organization of the United Nations, Rome, Italy, ISBN-13: 9789251060292, Pages: 192.

FAO, 2010a. Feather meal, feather meal, hydrolyzed feather meal, poultry feather meal, hydrolyzed poultry feather meal, keratin meal. Animal Feed Resources Information System. http:/www. fao.org/ ag/ aga/ agap/frg/afris/Data/326.HTM. 
FAO, 2010b. Poultry by-products meal. Animal Feed Resources Information System. http://www. fao. org/ AG/aGa/agap/FRG/afris/Data/325.htm.

FAS, 2010. Oilseeds: World markets and trade. Foreign Agricultural Service, Washington, DC., USA. http://www.fas.usda.gov/psdonline/circulars/oilsee ds.pdf.

FIN, 2009. Fishmeal and fish oil-summary. Fishmeal Information Network, London, UK. http://www. gafta. com/fin/index.php?pge_id=14.

Fagbenro, O., K. Jauncey and R. Krueger, 1997. Nutritive value of dried lactic acid fermented fish silage and soybean meal in dry diets for juvenile catfish, Clarias gariepinus (Burchell, 1822). J. Applied Ichthyol., 13: $27-30$,

Fagbenro, O.A. and K. Jauncey, 1994. Chemical and nutritional quality of dried fermented fish silages and their nutritive value for tilapia (Oreochromis niloticus). Animal Feed Sci, Technol., 45: 167-176.

Fan, M.Z. and W.C. Sauer, 1995. Determination of apparent ileal amino acid digestibility in barley and canola meal for pigs with the direct, difference and regression methods. J. Animal Sci., 73: $2364-2374$.

Farhangi, M. and C.G. Carter, 2001. Growth, physiological and immunological responses of rainbow trout (Oncorhynchus mykiss) to different dietary inclusion levels of dehulled lupin (Lupinus angustifolius). Aquacult. Res., 32: 329-340.

Fasakin, E.A., R.D. Serwata and S.J. Davies, 2005. Comparative utilization of rendered animal derived products with or without composite mixture of soybean meal in hybrid tilapia (Oreochromis niloticus $\mathrm{x}$ Oreochromis mossambicus) diets. Aquaculture, 249: 329-338.

Fekete, S.G., I. Hullar, E. Andrasofszky and F. Kelemen, 2004. Effect of different fibre types on the digestibility of nutrients in cats. J. Animal Physiol. Animal Nutr., 88: 138-142.

Ferraz de Arruda, L., R. Borghese and M. Oetterer, 2007. Use of fish waste as silage-A review. Brazilian Arch. Biol. Technol., 50: 879-886.

Francis, G., H.P.S. Makkar and K. Becher, 2001. Antinutritional factors present in plant-derived alternate fish ingredients and their effects in fish. Aquaculture, 199: 197-227.

Furuya, W.M., L.E. Pezzato, M.M. Barros, A.C. Pezzato, V.R.B. Furuya and E.C. Miranda, 2004. Use of ideal protein concept for precision formulation of amino acid levels in fish meal-free diets for juvenile Nile tilapia (Oreochromis niloticus L.). Aquaculture Res., 35: $1110-1116$.
Garcia, R.A. and K.A. Rosentrater, 2008. Concentration of key elements in North American meat and bone meal. Biomass Bioenergy, 32: 887-891.

Geron, L.J., L.M. Zeoula, R.M. Vidotti, M. Matsushita, R. Kazama and S.F.C. Neto, 2007. Chemical characterization, dry matter and crude protein ruminal degradability and in vitro intestinal digestion of acid and fermented silage from tilapia filleting residue. Anim. Feed Sci. Technol., 136: 226-239.

Gillund, F. and A.I. Myhr, 2010. Perspectives on salmon feed: A deliberative assessment of several alternative feed resources. J. Agricul. Environ. Ethics, 23: $527-550$.

Glencross, B., W. Hawkins and J. Curnow, 2004. Nutritional assessment of Australian canola meals. II. Evaluation of the influence of the canola oil extraction method on the protein value of canola meals fed to the red seabream (Pagrus auratus, Paulin). Aquac. Res., 35: 25-34.

Glencross, B., D. Evans, K. Dods, P. McCafferty and W. Hawkins, R. Maas and S. Sipsas, 2005. Evaluation of the digestible value of lupin and soybean protein concentrates and isolates when fed to rainbow trout, Oncorhynchus mykiss, using either stripping or settlement fecal collection methods. Aquaculture, 245: 211-220.

Glencross, B., W. Hawkins, C. Veitch, K. Dods, P. McCafferty and R. Hauler, 2007. The influence of dehulling efficiency on the digestible value of lupin (Lupinus angustifolius) kernel meal when fed to rainbow trout (Oncorhynchus mykiss). Aquacul. Nut., 13: $462-470$.

Goda, A.M.A.S., M.A. Wafa, E.R. El-Haroun, and M.A.K. Chowdhury, 2007. Growth performance and feed utilization of Nile tilapia Oreochromis niloticus (Linnaeus, 1758) and tilapia galilae Sarotherodon galilaeus (Linnaeus, 1758) fingerlings fed plant protein-based diets. Aquacult. Res., 38: 827-837.

Goddard, S., G. Al-Shagaa and A. Ali, 2008. Fisheries bycatch and processing waste meals as ingredients in diets for Nile tilapia, Oreochromis niloticus. Aquacult. Res., 39: 518-525.

Gomes, E.F., P. Rema and S.J. Kaushik, 1995. Replacement of fish meal by plant proteins in the diet of rainbow trout (Oncorhynchus mykiss): Digestibility and growth performance. Aquaculture, 130: 177-186.

Gouveia, A. and S.J. Davies, 1998. Preliminary nutritional evaluation of pea seed meal Pisum sativum for juvenile European sea bass Dicentrarchus labrax. Aquaculture, 166: 311-320. 
Guimaraes, I.G., L.E. Pezzato and M.M. Barros, 2008. Amino acid availability and protein digestibility of several protein sources for Nile tilapia, Oreochromis niloticus. Aquacult. Nut., 14: 396-404.

Gyori, Z., E. Nemeskeri and S. Szilagyi, 1998. Legumes grown under nonirrigated conditions. J. Agric. Food Chem., 46: 3087-3091.

Hajen, W.E., D.A. Higgs, R.M. Beames and B.S. Dosanjh, 1993. Digestibility of various feedstuffs by postjuvenile chinook salmon (Oncorhynchus tshawytscha) in sea water. 2. Measurement of digestibility. Aquacult., 112: 333-348.

Hammoumi, A., M. Faid, M. El Yachioui and H. Amarouch, 1998. Characterization of fermented fish waste used in feeding trials with broilers. Process Biochem., 33: 423-427.

Hardy, R.W. and A.J.G. Tacon, 2002. Fish Meal-historical Uses, Production Trends and Future Outlook for Sustainable Supplies, In: In: Responsible Marine Aquaculture, Stickney, R.R. and J.P. McVey (Eds.)., CABI Publishing, Oxon, UK, pp: 311-325.

Hardy, R.W., 1996. Alternate protein sources for salmon and trout diets. Anim. Sci. Technol., 59: 71-80.

Hardy, R.W., K.D. Shearer, F.E. Stone and D.H. Wieg, 1983. Fish silage in aquaculture diets. J. World Aquacult. Soci., 14: 695-703.

Hardy, R.W., W.M. Sealy and D.M. Gatlin III, 2005. Fisheries by-catch and byproduct meals as protein sources for rainbow trout Oncorhynchus mykiss. J. World Aquacult. Soci., 36: 393-400.

Hardy, W.R., 2000. New Developments in Aquatic Feed Ingredients and Potential of Enzyme Supplements. In: Advances en Nutricion Acuicola V. Memorias del V Simposium Internacional de Nutricion Acuicola, CruzSuarez, L.E., D. Ricque-Marie, M. Tapia-Salazar, M.A.Y. Olvera-Novoa and R. Civera-Cerecedo (Eds.). Merida, Yucatan, Mexico, pp: 216-226.

Harnly, J.M., M.A. Pastor-Corrales and D.L. Luthria, 2009. Variance in the chemical composition of dry beans determined from UV spectral fingerprints. J. Agricult. Food Chem., 57: 8705-8710.

Harrington, J.M., R.A. Myers and A.A. Rosenberg, 2005. Wasted fishery resources: Discarded by-catch in the USA. Fish. Fisher., 6: 350-361.

Hasan, M.R., M.S. Haq, P.M. Das and G. Mowlah, 1997. Evaluation of poultry-feather meal as a dietary protein source for Indian major carp, Labeo rohita fry. Aquaculture, 151: 47-54.

Hernandez, C., M.A. Olvera-Novoa, K. Aguilar-Vejar, B. Gonzalez-Rodríguez and I. Abdo de la Parra, 2008. Partial replacement of fish meal by porcine meat meal in practical diets for Pacific white shrimp (Litopenaeus vannamei). Aquaculture, 277: 244-250.
Hernandez, C., M.A. Olvera-Novoa, R.W. Hardy, A. Hermosillo, C. Reyes andB. Gonzalez, 2010. Complete replacement of fish meal by porcine and poultry byproduct meals in practical diets for fingerling Nile tilapia Oreochromis niloticus: Digestibility and growth performance. Aquac. Nut., 16: 44-53.

Hoover, R. and W.S. Ratnayake, 2002. Starch characteristics of black bean, chick pea, lentil, navy bean and pinto bean cultivars grown in Canada. Food Chem., 78: 489-498.

Hossain, M.A., N. Nahar and M. Kamal, 1997. Nutrient digestibility coefficients of some plant and animal proteins for rohu (Labeo rohita). Aquaculture, 151: $37-45$.

Hughes, S.G., 1988. Assessment of lupin flour as a diet ingredient for rainbow trout (Salmo gairdneri). Aquaculture, 71: 379-385.

Ingredients101, 2010a. 60\% corn gluten meal. http://ingredients 101.com/cgm.htm.

Ingredients 101, 2010b. Blood meal, whole. http:// ingredients $101 . \mathrm{com} /$ bloodmeal.htm.

Ingredients101, 2010c. Corn gluten feed. http:// ingredients $101 . \mathrm{com} / \mathrm{cgf.htm}$.

Ingredients101, 2010d. Cottonseed meal. http:// ingredients $101 . \mathrm{com} /$ cottonmeal.htm.

Ingredients 101, 2010e. Feather meal. http:// ingredients $101 . \mathrm{com} /$ feather.htm.

Ingredients101, 2010f. Fish meal, menhaden. http://ingredients101.com/fishmeal.htm.

Iqbal, A., I.A. Khalil, N. Ateeq and M.S. Khan, 2006. Nutritional quality of important food legumes. Food Chem., 97: 331-335.

Jackson, A., 2009. The continuing demand for sustainable fishmeal and fish oil in aquaculture diets. http://en.engormix.com/MA-aquaculture/ nutrition/ articles/the-continuing-dem and-sustainable_ 1437.htm.

Jackson, A.J., A.K. Kerr and C.B. Cowey, 1984. Fish silage as a dietary ingredient for salmon. I. Nutr. Storage Characteristics. Aqualculture, 38: 211-220.

Jacques, K.A., T.P. Lyons and D.R. Kelsall, 2003. The Alcohol Textbook. 4th Edn., Nottingham University Press, Nottingham, UK., Pages: 379.

Kakade, M.L. and R.J. Evans, 1966. Growth inhibition of rats fed raw navy beans (Phaseolus vulgaris). J. Nut., 90: 191-198.

Kats, L.J., J.L. Nelssen, M.D. Tokach, R.D. Goodband, T.L. Weeden, S.S. Dritz, J.A. Hansen and K.G. Friesen, 1994. The effects of spray-dried blood meal on growth performance of the early-weaned pig. J. Anim. Sci., 72: 2860-2869. 
Kaushik, S.J., J.P. Cravedi, J.P. Lalles, J. Sumpter, B. Fauconneau and M. Laroche, 1995. Partial or total replacement of fish meal by soybean protein on growth, protein utilization, potential estrogenic or antigenic effects, cholesterolemia and flesh quality in rainbow trout, Oncorhynchus mykiss. Aquaculture, 133: $257-274$.

Khattab, R.Y., S.D Arntfield and C.M. Nyachoti, 2009. Nutritional quality of legume seeds as affected by some physical treatments. Part 1: Protein quality evaluation. LWT-Food Sci. Technol., 42: 1107-1112.

Kherrati, B., M. Faid, M. Elyachioui and A. Wahmane, 1998. Process for recycling slaughterhouses wastes and byproducts by fermentation. Bioresour. Technol., 63: 75-79.

Kikuchi, K., 1999. Partial replacement of fish meal with corn gluten meal in diets for Japanese flounder Paralichthys olivaceus. J. World Aquaculture Soc., 30: 357-363.

Kikuchi, K., T. Sato, T. Furuta, I. Sakaguchi and Y. Deguchi, 1997. Use of meat and bone meal as a protein source in the diet of juvenile Japanese flounder. Fish. Sci., 63: 29-32.

Kim, S.W. and R.A. Easter, 2001. Nutritional value of fish meals in the diet for young pigs. J. Anim. Sci., 79: 1829-1839.

WKop, A. and A.Y. Korkut, 2010. Effects of diets with different fish meal origins on the performance of rainbow trout Oncorhynchus mykiss (Walbaum). J. Anim. Vet. Adv., 9: 581-583.

Kuo, Y.H., P. Rozan, F. Lambein, J. Frias and C. VidalValverde, 2004. Effects of different germination conditions on the contents of free protein and nonprotein amino acids of commercial legumes. Food Chem., 86: 537-545.

.Lardy, G.P. and M.S. Kerley, 1994. Effect of increasing the dietary level of rapeseed meal on intake by growing beef steers. J. Anim. Sci., 72: 1936-1942.

Lee, D.J. and G.B. Putnam, 1973. The response of rainbow trout to varying protein/energy ratios in a test diet. J. Nutr., 103: 916-922.

Li, M.H., B.C. Peterson, C.L. Janes and E.H. Robinson, 2006. Comparison of diets containing various fish meal levels on growth performance, body composition and insulin-like growth factor-I of juvenile channel catfish Ictalurus punctatus of different strains. Aquaculture, 253: 628-635.

Li, P., X. Wang, R.W. Hardy and D.M. Gatlin, 2004. Nutritional value of fisheries by-catch and byproduct meals in the diet of red drum (Sciaenops ocellatus). Aquaculture, 236: 485-496.
Lie, O., R. Waagbo and K. Sandnes, 1998. Growth and chemical composition of adult Atlantic salmon (Salmo salar) fed dry and silage-based diets. Aquaculture, 69: 343-353.

Lim, C., J.C. Garcia, M. Yildirim-Aksoy, P.H. Klesius, C.A. Shoemaker and J.J. Evans, 2007. Growth response and resistance to Streptococcus iniae of Nile tilapia, Oreochromis niloticus, fed diets containing distiller's dried grains with solubles. J. World Aquacult. Soc., 38: 231-237.

Lim, C., M. Yildirim-Aksoy andP.H. Klesius, 2009. Growth response and resistance to Edwardsiella ictaluri of channel catfish, Ictalurus punctatus, fed diets containing distiller's dried grains with solubles. J. World Aquacult. Soc., 40: 182-193.

Lin, Y.H. and S.Y. Shiau, 2003. Dietary lipid requirement of grouper, Epinephelus malabaricus and effects on immune responses. Aquaculture, 225: 243-250.

Liu, H., X. Wu, W. Zhao, M. Xue, L. Guo, Y. Yu and Y. Zheng, 2009. Nutrients apparent digestibility coefficients of selected protein sources for juvenile Siberian sturgeon (Acipenser baerii Brandt), compared by two chromic oxide analyses methods. Aquacult. Nutr., 15: 650-656.

Lunger, A.N., E. McLean and S.R. Craig, 2007. The effects of organic protein supplementation upon growth, feed conversion and texture quality parameters in juvenile cobia (Rachycentron canadum). Aquaculture, 264: 342-352.

Lusas, E.W. and M.N. Riaz, 1995. Soy protein products: Processing and use. J. Nutr., 125: 573S-580S.

Luzier, J.M., R.C. Summerfelt and H.G. Ketola, 1995. Partial replacement of fish meal with spray-dried blood powder to reduce phosphorus concentrations in diets for juvenile rainbow trout, Oncorhynchus mykiss (Walbaum). Aquacult. Res., 26: 577-587.

Mariscal-Landin, G., Y. Lebreton and B. Seive, 2002. Apparent and standardised true ileal digestibility of protein and amino acids from faba bean, lupin and pea, provided as whole seeds, dehulled or extruded in pig diets. Anim. Feed Sci. Technol., 97: 183-198.

Martin-Cabrejas, M.A., Y. Aguilera, M.M. Pedrosa, C. Cuadrado, T. Hernandez, S. Diaz and R.M. Esteban, 2009. The impact of dehydration process on antinutrients and protein digestibility of some legume flours. Food Chem., 114: 1063-1068.

Martinez-Llorens, S., A.T. Vidal, A.V. Monpino, J.G. Ader, M.P. Torres and M.J. Cerdai, 2008. Blood and haemoglobin meal as protein sources in diets for gilthead sea bream (Sparus aurata): Effects on growth, nutritive efficiency and fillet sensory differences. Aquacult. Res., 39: 1028-1037. 
Martinez-Villaluenga, C., J. Frias and C. Vidal-Valverde, 2006. Functional lupin seeds (Lupinus albus L. and Lupinus luteus L.) after extraction of á-galactosides. Food Chem., 98: 291-299.

Meiners, C.R., N.L. Derise, H.C. Lau, S.J. Ritchey and E.W. Murphy, 1976. Proximate composition and yield of raw and cooked mature dry legumes. J. Agric. Food Chem., 24: 1122-1126.

Mesomya, W., Y. Cuptapun, P. Jittanoonta, D Hengsawadi, S. Boonvisut, P. Huttayanon and W. Sriwatana, 2002. Nutritional evaluations of green catfish, Mystus nemurus. Kasetsart J. Nat. Sci., 36: 69-74.

Metts, L.S., K.R. Thompson, Y. Xiong, B. Kong, C.D. Webster and Y. Brady, 2007. Use of alfalfa hay, compared to feeding practical diets containing two protein levels, on growth, survival, body composition and processing traits of Australian red claw crayfish, Cherax quadricarinatus, grown in ponds. J. World Aquacult. Soc., 38: 218-230.

Meyers, S.P., 1994. Developments in world aquaculture, feed formulations and role of carotenoids. Pure Applied Chem., 66: 1069-1076.

Millamena, O.M., 2002. Replacement of fish meal by animal byproduct meals in a practical diet for growout culture of grouper Epinephelus coioides. Aquaculture, 204: 75-84.

Murray, H.M., S.P. Lall, R. Rajaselvam, L.A. Boutilier and B. Blanchard et al., 2010. A nutrigenomic analysis of intestinal response to partial soybean meal replacement in diets for juvenile Atlantic halibut, Hippoglossus hippoglossus, L. Aquaculture, 298: 282-293.

Mustafa, A.F., P.A. Thacker, J.J. McKinnon, D.A. Christensen and V.J. Racz, 2000. Nutritional value of feed grade chickpeas for ruminants and pigs. J. Sci. Food Agric., 80: 1581-1588.

Myer, B. and M. Hersom, 2008. Corn gluten feed for beef cattle. Department of Animal Sciences, Florida Cooperative Extension Service, Institute of Food and Agricultural Sciences, University of Florida, USA. http://edis.ifas.ufl.edu/an201.

NRC, 1993. Nutrient Requirements of Fish. National Academy Press, National Research Council, Washington, DC., USA.

NRC, 1998. Nutrient Requirements of Swine. 10th Edn., National Academy Press, National Research Council, Washington, DC., USA.

NRC, 2001. Nutrient Composition of Feeds. In: Nutrient Requirements of Beef Cattle, NRC (Ed.). 7th Edn. National Academy Press, National Research Council, Washington, D., USA., pp: 283-303.
Naylor, R.L., R.J. Goldburg, H. Mooney, M. Beveridge and J. Clay et al., 1998. Nature's subsidies to shrimp and salmon farming. Nature, 405: 1017-1024.

Nestares, T., M. Lopez-Frias, M. Barrionuevo and G. Urbano, 1996. Nutritional assessment of raw and processed chickpea (Cicer arietinum L.) protein in growing rats. J. Agric. Food Chem., 44: $2760-2765$.

Nguyen, T.N., D.A. Davis and I.P. Saoud, 2009. Evaluation of alternative protein sources to replace fish meal in practical diets for juvenile tilapia, Oreochromis sp. J. World Aquacult. Soc., 40: 113-121.

Oliva-Teles, A., A.J. Gouveia and E. Gomes, 1994. The effect of different processing treatments on soybean meal utilization by rainbow trout, Oncorhynchus mykiss. Aquaculture, 124: 343-349.

Olvera, N.M.A., G.S. Campos, G.M. Sabido and P.C.A. Martinez, 1990. The use of alfalfa leaf protein concentrates as a protein source in diets for tilapia (Oreochromis mossambicus). Aquaculture, 90: 291-302.

Otubusin, S.O., 1987. Effects of different levels of blood meal in pelleted feeds on tilapia, Oreochromis niloticus, production in floating bamboo net-cages. Aquaculture, 65: 263-266.

Overland, M., O.H. Romarheim, M. Hovin, T. Storebakken and A. Skrede, 2006. Apparent total tract digestibility of unprocessed and extruded diets containing basic and autolyzed bacterial protein meal grown on natural gas in mink and rainbow trout. Anim. Feed Sci. Technol., 129: 237-251.

Overland, M., M. Sørensen, T. Storebakken, M. Penn, A. Krogdahl and A. Skrede, 2009. Pea protein concentrate substituting fish meal or soybean meal in diets for Atlantic salmon (Salmo salar)-Effect on growth performance, nutrient digestibility, carcass composition, gut health and physical feed quality. Aquaculture, 288: 305-311.

Paduano, D.C., R.M. Dixon, J.A. Domingo and J.H.G. Holmes, 1995. Lupin (Lupinus angustifolius), cowpea (Vigna unguiculata) and navy bean (Phaseolus vulgaris) seeds as supplements for sheep fed low quality roughage. Anim. Feed Sci. Technol., 53: $55-69$.

Pagarkar, A.U., S. Basu, A. Mitra and N.P. Sahu, 2006. Preparation of bio-fermented and acid silage from fish waste and its biochemical characteristic. Asian J. Microbiol., Biotechnol. Env. Sci., 8: 381-387.

Pereira, T.G. and A. Oliva-Teles, 2002. Preliminary evaluation of pea seed meal in diets for gilthead sea bream (Sparus aurata) juveniles. Aquaculture Res., 33: $1183-1189$. 
Pereira, T.G. and A. Oliva-Teles, 2003. Evaluation of corn gluten meal as a protein source in diets for gilthead sea bream (Sparus aurata L.) juveniles. Aquaculture Res., 34: 1111-1117.

Peres, H. and A. Oliva-Teles, 1999. Effect of dietary lipid level on growth performance and feed utilization by European sea bass juveniles (Dicentrarchus labrax). Aquaculture, 179: 325-334.

Peterson, C.L. and T. Hustrulid, 1998. Carbon cycle for rapeseed oil biodiesel fuels. Bio. Bioenergy, 14: $91-101$.

Pine, H.J., W.H. Daniels, D.A. Davis, M. Jiang and C.D. Webster, 2008. Replacement of fish meal with poultry byproduct meal as a protein source in pond-raised sunshine bass, Morone chrysops ㅇ x M. saxatlis $0^{*}$, diets. Journal World Aquaculture Soc., 39: 586-597.

Pisarikova, B., Z. Zraly, F. Bunka and M. Trckova, 2008. Nutritional value of white lupine cultivar Butan in diets for fattening pigs. Veterinarni Med., 53: 124-134.

Rawles, S.D., T.G. Gaylord, M.E. McEntire and D.W. Freeman, 2009. Evaluation of poultry by-product meal in commercial diets for hybrid striped bass, Morone chrysops? x Morone saxatilis?, in pond production. J. World Aquacult. Soc., 40: 141-156.

Rawles, S.D., K.R. Thompson, Y.J. Brady, L.S. Metts, A.L. Gannam, R.G. Twibell and C.D. Webster, 2010. A comparison of two faecal collection methods for protein and amino acid digestibility coefficients of menhaden fish meal and two grades of poultry byproduct meals for market-size sunshine bass (Morone chrysops x M. saxatilis). Aquacult. Nutr., 16: 81-90.

Raymer, P.L., 2002. Canola: AnEmerging Oilseed Crop. In: Trends in New Crops and New Uses, Janick, J. and A. Whipkey (Eds.). ASHS Press, Alexandira, VA., USA., pp: 122-126.

Reddy, N.R., M.D. Pierson, S.K. Sathe and D.K. Salunkhe, 1985. Dry bean tannins: A review of nutritional implications. J. Am. Oil Chem. Soc., 62: 541-549.

Refstie, S., O. Korsoen and T. Storebakken, 2000. Differing nutritional responses to dietary soybean meal in rainbow trout (Oncorhynchus mykiss) and Atlantic salmon (Salmo salar). Aquaculture, 190: 49-63.

Regost, C., J. Arzel and S.J. Kaushik, 1999. Partial or total replacement of fish meal by corn gluten meal in diet for turbot, Psetta maxima. Aquaculture, 180: 90-117.

Regost, C., J. Arzel, M. Cardinal, M. Laroche and S.J. Kaushik, 2001. Fat deposition and flesh quality in seawater reared, triploid brown trout (Salmo trutta) as affected by dietary fat levels and starvation. Aquaculture, 193: 325-345.
Reis, L.M., E.M. Reutebuch and R.T. Lovell, 1989. Proteinto-energy ratios in production diets and growth, feed conversion and body composition of channel catfish, Ictalurus punctatus. Aquaculture, 77: 21-27.

Robaina, L., M.S. Izquierdo, F.J. Moyano, J. Socorro, J.M. Vergara, D. Montero and H. Fernandez-Palacios, 1995. Soybean and lupin seed meals as protein sources in diets for gilthead sea bream (Sparus aurata): Nutritional and histological implications. Aquaculture, 130: 219-233.

Robaina, L., F.J. Moyano, M.S. Izquierdo, J. Socorro, J.M. Vergara and D. Montero, 1997. Corn gluten and meat and bone meals as protein sources in diets for gilthead seabream (Sparus aurata): Nutritional and histological implications. Aquaculture, 157: 347-359.

Robinson, E.H. and M.H. Li, 1994. Use of plant proteins in catfish feeds: Replacement of soybean meal with cottonseed meal and replacement of fish meal with soybean meal and cottonseed meal. J. World Aquacul. Soc., 25: 271-276.

Robinson, E.H. and M.H. Li, 2008. Replacement of soybean meal in channel catfish, Ictalurus punctatus diets with cottonseed meal and distiller's dried grains with solubles. J. World Aquacul. Soc., 39: 521-527.

Robinson, E.H., M.H. Li and B.B. Manning, 2001. Evaluation of corn gluten feed as a dietary ingredient for pond-raised channel catfish Ictalurus punctatus. J. World Aquacul. Soc., 32: 68-71.

Rosentrater, K.A. and K. Muthukumarappan, 2006. Corn ethanol coproducts: Generation, properties and future prospects. Int. Sugar J., 108: 648-657.

Rozan, P., Y.H. Kuo and F. Lambein, 2001. Amino acids in seeds and seedlings of the genus Lens. Phytochemistry, 58: 281-289.

Rustand, T., 2003. Utilisation of marine byproduct. Electron. J. Environ. Agric. Food Chem., 2: 458-463.

Salgado, P., J.P. Lalles, R. Toullec, M. Mourato, F. Cabral and J.P.B. Freire, 2001. Nutrient digestibility of chickpea (Cicer arietinum L.) seeds and effects on the small intestine of weaned piglets. Anim. Feed Sci. Technol., 91: 197-212.

Salunkhe, D.K. and S.S. Kadam, 1989. Handbook of World Food Legumes: Nutritional Processing Technology and Utilization, Vol.1., CRC Press, Boca Raton, FL.

Salze, G., E. McLean, P. Rush Battle, M.H. Schwarz and S.R. Craig, 2010. Use of soy protein concentrate and novel ingredients in the total elimination of fish meal and fish oil in diets for juvenile cobia, Rachycentron canadum. Aquaculture, 298: 294-299. 
Sanchez-Lozano, N.B., S. Martinez-Llorens, A. TomasVidal and M.J. Cerda, 2009. Effect of high-level fish meal replacement by pea and rice concentrate protein on growth, nutrient utilization and fillet quality in gilthead sea bream (Sparus aurata, L.). Aquaculture, 298: 83-89.

Satoh, S., A. Hernandez, T. Tokoro, Y. Morishita, V. Kiron and T. Watanabe, 2003. Comparison of phosphorus retention efficiency between rainbow trout (Oncorhynchus mykiss) fed a commercial diet and a low fish meal based diet. Aquaculture, 224: 271-277.

Sauvant, D., 2004. Tables of Composition and Nutritional Value of Feed Materials: Pigs, Poultry, Cattle, Sheep, Goats, Rabbits, Horses and Fish. 2nd Edn., Wageningen Academic Publishers, Wageningen, The Netherlands, ISBN-13: 9789076998411 , Pages: 304.

Schroeder, J.W., 1997. Corn gluten feed: Composition, storage, handling, feeding and value. North Dakota State University Agriculture and University Extension, Fargo, ND., USA.

Sevgili, H. and M.M. Erturk, 2004. Effects of replacement of fish meal with poultry byproduct meal on growth performance in practical diets for rainbow trout, Oncorhynchus mykiss. Akdeniz Universitesi Ziraat Fakültesi Dergisi, 17: 161-167.

Shahidi, F., 1990. Canola and Rapeseed: Production, Chemistry, Nutrition and Processing Technology. Van Nostrand Reinhold, New York, pp: 355.

Shirley, R.B. and C.M. Parsons, 2001. Effect of ash content on protein quality of meat and bone meal. Poult. Sci., 80: 626-632.

Siddiq, M., R. Ravi, J.B. Harte and K.D. Dolan, 2010. Physical and functional characteristics of selected dry bean (Phaseolus vulgaris L.) flours. LWT-Food Sci. Technol., 43: 232-237.

Sirtori, C.R., M.R. Lovati, C. Manzoni, S. Castiglioni and M. Duranti et al., 2004. Proteins of white lupin seed, a naturally isoflavone-poor legume, reduce cholesterolemia in rats and increase LDL receptor activity in HepG2 cells. J. Nutr., 134: 18-23.

Skrede, A., G.M. Berge, T. Storebakken, O. Herstad, K.G. Aarstad and F. Sundstol, 1998. Digestibility of bacterial protein grown on natural gas in mink, pigs, chicken and Atlantic salmon. Anim. Feed Sci. Technol., 76: 103-116.

Sosulski, F. and R. Zadernowski, 1981. Fractionation of rapeseed meal into hour and hull components. J. Am. Oil Chem. Soc., 58: 96-98.

Sotelo, A., H. Sousa and M. Sanchez, 1995. Comparative study of the chemical composition of wild and cultivated beans (Phaseolus vulgaris). Plant Foods Hum. Nutr., 47: 93-100.
Steffens, W., 1994. Replacing fish meal with poultry byproduct meal in diets for rainbow trout, Oncorhynchus mykiss. Aquaculture, 124: 27-34.

Stein, H.H., M.L. Gibson, C. Pedersen and M.G. Boersma, 2006. Amino acid and energy digestibility in ten samples of distillers dried grain with solubles fed to growing pigs. J. Anim. Sci., 84: 853-860.

Stone, F.E., R.W. Hardy, K.D. Shearer and T.M. Scott, 1989. Utilization of fish silage by rainbow trout (Salmo gairdneri). Aquaculture, 76: 109-118.

Storebakken, T., G. Baeverfjord, A. Skrede, J.J. Olli and G.M. Berge, 2004. Bacterial protein grown on natural gas in diets for Atlantic salmon, Salmo salar, in freshwater. Aquaculture, 24: 413-425.

Sujak, A., A. Kotlarz and W. Strobel, 2006. Compositional and nutritional evaluation of several lupin seeds. Food Chem., 98: 711-719.

Swain, S.N., S.M. Biswal, P.K. Nanda and P.L. Nayak, 2004. Biodegradable soy-based plastics: opportunities and challenges. J. Polym. Environ., 12: $35-42$.

Takagi, S., H. Murata, T. Goto, M. Endo, H. Yamashita and M. Ukawa, 2008. Taurine is an essential nutrient for yellowtail Seriola quinqueradiata fed non-fish meal diets based on soy protein concentrate. Aquaculture, 280: 198-205.

Tatterson, I.N. and M.L. Windsor, 1974. Fish silage. J. Sci. Food Agric., 25: 369-379.

The FishSite, 2010. Utilisation of plant proteins in fish diets. 5M Enterprises Ltd. Available at: http:/www.thefishsite.com/articles/523/utilisation-ofplant-proteins-in-fish-diets.

The Jacobsen, 2010. The Jacobsen Publishing Company: Chicago, IL. Available at: http://www.thejacobsen. com.

Thiessen, D.L., G.L. Campbell and P.D. Adelizi, 2003. Digestibility and growth performance of juvenile rainbow trout (Oncorhynchus mykiss) fed with pea and canola products. Aquac. Nutr., 9: 67-75.

Thompson, K.R., L.S. Metts, L.A. Muzinic, S. Dasgupta and C.D. Webster, 2007. Use of Turkey meal as a replacement for menhaden fish meal in practical diets for sunshine bass grown in cages. North Am. J. Aquacult., 69: 351-359.

Thompson, K.R., S.D. Rawles, L.S. Metts, R. Smith and A. Wimsatt et al., 2008. Digestibility of dry matter, protein, lipid and organic matter of two fish meals, two poultry by-product meals, soybean meal, and distiller's dried grains with solubles in practical diets for sunshine bass, Morone chrysops x M. saxatilis. J. World Aquacult. Soc., 39: 352-363. 
Thompson, M.D., M.A. Brick, J.N. McGinley and H.J. Thompson, 2009. Chemical composition and mammary cancer inhibitory activity of dry bean. Crop Sci., 49: 179-186.

Tibbetts, S.M., E. Milley and S.P. Lall, 2006. Apparent protein and energy digestibility of common and alternative feed ingredients by Atlantic cod, Gadus morhua (Linnaeus, 1758). Aquaculture, 261: 1314-1327.

USB, 2008. Nutrient specifications and quality standards for ingredients commonly used in diets for aquaculture species. U.S. Soybean Export Council, USA.

USDA, 2010a. Byproduct feeds: Average wholesale price, bulk, specified markets. Feed grains data: Yearbook tables. United States Department of Agriculture, Agricultural Marketing Service, Washington, DC., USA.

USDA, 2010b. Dry beans. United States Department of Agriculture, Economic Research Service, Washington, DC., USA.

USDA, 2010c. Dry peas. United States Department of Agriculture, National Agricultural Statistics Service, Washington, DC., USA.

USDA, 2010d. Lentils. United States Department of Agriculture, National Agricultural Statistics Service, Washington, DC., USA.

USDA, 2010e. Soybeans and oil crops: Canola. United States Department of Agriculture, Economic Research Service, Washington, DC., USA. http://www.ers.usda.gov/Briefing/SoybeansOilcrop s/Canola.htm\#canolaprod.

USDA, 2010f. World soybeans and products supply and distribution. United States Department of Agriculture, Foreign Agricultural Service, Washington, DC., USA.

USSEC, 2010. Soy protein concentrate for aquaculture feeds. Technical Bulletin, Soybean Export Council, St. Louis, MO., USA. http://www.ussoyexports. org/ resources/SPCforaquaculture.pdf.

Van Der Poel, A., 1990. Effect of processing on antinutritional factors and protein nutritional value of dry beans (Phaseolus vulgaris L.). A review. Anim. Feed Sci. Technol., 29: 179-208.

Vidal-Valverde, C., J. Frias, I. Estrella, M.J. Gorospe, R. Ruiz and J. Bacon, 1994. Effect of processing on some antinutritional factors of lentils. J. Agric. Food Chem., 42: 2291-2295.

Vidoiti, R.M., D.J. Carneiro and E.M.M. Viegas, 2002. Acid and fermented silage characterization and determination of apparent digestibility coefficient of crude protein for pacu Piaractus mesopotamicus. J. World Aquacult. Soc., 33: 57-62.
Wang, C. and L.A. Johnson, 2001. Functional properties of hydrothermally cooked soy protein products. J. Am. Oil Chem. Soc., 78: 189-195.

Wang, N. and J.K. Daun, 2006. Effects of variety and crude protein content on nutrients and antinutrients in lentils (Lens culinaris). Food Chem., 95: 493-502.

Wang, N., D. Hatcher, R. Toews and E. Gawalko, 2009. Influence of cooking and dehulling on nutritional composition of several varieties of lentils (Lens culinaris). LWT Food Sci. Technol., 42: 842-848.

Wang, N., D.W. Hatcher, R.T. Tyler, R. Toews and E.J. Gawalko, 2010a. Effect of cooking on the composition of beans (Phaseolus vulgaris L.) and chickpeas (Cicer arietinum L.). Food Res. Int., 43: 589-594.

Wang, Y., L. Kong, C. Li and D. Bureau, 2010b. The potential of land animal protein ingredients to replace fish meal in diets for cuneate drum, Nibea miichthioides, is affected by dietary protein level. Aquacult. Nutr., 16: 37-43.

Webster, C.D., J.H. Tidwell and L.S. Goodgame, 1993. Growth, body composition, and organoleptic evaluation of channel catfish fed diets containing different percentages of distillers9 grains with solubles. Progr. Fuh-Cullurist, 55: 95-100.

Webster, C.D., K.R. Thompson, A.M. Morgan, E.J. Grisby and A.L. Gannam, 2000. Use of hempseed meal, poultry by-product meal, and canola meal in practical diets without fish meal for sunshine bass (Morone chrysops x M. saxatilis). Aquaculture, 188: 299-309.

Whiteman, K.W. and D.M. Gatlin, 2005. Evaluation of fisheries by-catch and by-product meals in diets for red drum Sciaenops ocellatus L. Aquacult. Res., 36: $1572-1580$.

Wilson, R.P., 1994. Utilization of dietary carbohydrate by fish. Aquaculture, 124: 67-80.

Wu, Y.V., R.R. Rosati and P.B. Brown, 1996. Effect of diets containing various levels of protein and ethanol coproducts from corn on growth of tilapia fry. J. Agric. Food Chem., 44: 1491-1493.

Wu, Y.V., R.R. Rosati, D.J. Sessa and P.B. Brown, 1995. Evaluation of corn gluten meal as a protein source in tilapia diets. J. Agric. Food Chem., 43: 1585-1588.

Yagci, F.B., F. Alagil, I. Karayucel, S.U. Tiril and S. Dernekbasi, 2009. Evaluation of extruded chickpea, common bean and red lentil meals as protein source in diets for juvenile rainbow trout (Oncorhynchus mykiss). J. Anim. Vet. Adv., 8: 2079-2086. 
Yamamoto, T., T. Shima and H. Furuita, 2004. Antagonistic effects of branched-chain amino acids induced by excess protein-bound leucine in diets for rainbow trout (Oncorhynchus mykiss). Fish. Res., 232: 539-550.

Yanar, M., Z. Eren, A.Z. Hunt and H.M. Bykapar, 2008. The use of alfalfa, Medicago sativa as a natural carotenoid source in diets of goldfish, Carassius auratus. Aquaculture, 284: 196-200.

Yang, S., M. Gao, C. Xu, J. Gao and S. Deshpande et al., 2008. Alfalfa benefits from Medicago truncatula: The RCT1 gene from M. truncatula confers broadspectrum resistance to anthracnose in alfalfa. PNAS, 105: 12164-12169.
Yano, Y., H. Oikawa and M. Satomi, 2008. Reduction of lipids in fish meal prepared from fish waste by a yeast Yarrowia lipolytica. Int. J. Food Microbiol., 121: 302-307.

Yousif, O.M., G.A. Alhadrami and M. Pessarakli, 1994. Evaluation of dehydrated alfalfa and salt bush (Atriplex) leaves in diets for tilapia (Oreochromis aureus L.). Aquaculture, 126: 341-347.

Zielinska, A., H. Gorecka, H. Gorecki, I. Michalak, K. Chojnacka and M. Baranska, 2007. New role of sulfuric acid in production of multicomponent fertilizers from renewable sources. Am. J. Agric. Biol. Sci., 2: 241-247. 